\title{
Open-air site complex with leaf-points at Szécsénke (Cserhát Mountains, Northern Hungary) Preliminary results
}

\section{Péntek Attila}

\section{Abstract}

Based on extensive field surveys of the past decade the Late Middle Palaeolithic and Initial Upper Palaeolithic occupation was very intensive in the Cserhát Mountains. There are some very characteristic clusters in the site distribution. One of the important ones is those of in the vicinity of Legénd and Szécsénke villages. In this paper we will review the lithic material of an interpreted Palaeolithic site complex at Szécsénke village. The compound term „site complex“ does not necessary mean simultaneity of the affected sites, by this term rather a kind of techno-typological relation between the collected chipped stone assemblages will be stressed. The affected sites seem to have a Szeletian-like character which resembles the well researched Moravian Szeletian. On the base of the raw material utilization and of techno-typological considerations a kind of intra-cultural development can be observed.

Kivonat

\begin{abstract}
Nyíltszíni lelőhelykomplexum levélhegyekkel Szécsénkénél (Cserhát-hegység, Észak-Magyarország) elözetes eredmények

Az elmúlt évtized kiterjedt terepbejárásai alapján intenzív megtelepedéssel számolhatunk a Cserhát-hegységben a késő iközépső paleolitikum és a korai felső paleolitikum időszakában. A lelőhelyek megoszlása jellegzetes halmazokat rajzol ki. A jelentős lelőhelyek Legénd és Szécsénke környékén találhatók. A „lelőhelykomplexum” terminus nem feltétlenül jelez egyidejűséget a megtelepedések között, inkább kőanyagaik techno-tipológiai hasonlóságaira utal. A bemutatott lelőhelyek Szeleta ipar jellegzetességekkel rendelkeznek, összességében a morvaországi Szeleta iparra emlékeztetnek. A kőnyersanyagok használata, illetve techno-tipológiai megfontolások alapján egyfajta belső kulturális fejlődés is megfigyelhető a leletanyagokban.
\end{abstract}

Keywords

Cserhát Mountains, Northern Hungary, felsitic porphyry, leaf-shaped tool, Micoquian-Bábonyian industry, Szeletian industry, site complex, settlement dynamics, landscape use pattern

Kulcsszavak Cserhát-hegység, Észak-Magyarország, kvarcporfír, levéleszköz, Micoquien-Bábonyien ipar, Szeleta ipar, lelőhelykomplexum, település dinamika, tájhasználat mintázatai

\section{Author / Szerzö}

Cite as / Hivatkozás

Article history /

Kézirat történet

Copyright / Jogok

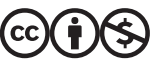

\section{H-2143 Kistarcsa, Késmárki utca 27. Email: attila.pentek@yahoo.com}

Péntek, A. (2015) Open-air site complex with leaf-points at Szécsénke (Cserhát Mountains, Northern Hungary). Preliminary results. Litikum 3: 47-70. https://doi.org/10.23898/litikuma0012

Received // Érkezés: 2015. 04 . 10. Accepted // Elfogadás: 2015. 06. 10. Published // Közzététel: 2016. 04. 25.

(c) 2015 Péntek. This is an open-access article distributed under the terms of the Creative Commons Attribution License, which permits unrestricted use, distribution, and reproduction in any medium, provided the original author and source are credited. // Ez egy nyílt hozzáférésű publikáció, amit a Creative Commons 4.0 licensze véd. A termék szabadon használható, terjeszthető és sokszorosítható az eredeti szerző és forrás megjelölése mellett.
„If you understand, things are such as they are;

if you don't understand, things are such as they are."

Zen Koan

\section{Introduction}

The discussed area next to Szécsénke is situated in Nógrád County, Northern Hungary, in the Western Cserhát Mountains, westwards from the Galga River. The river forms an important geological and geographical border between the Central and Eastern Cserhát Mountains of volcanic origin and the sedimentary Western Cserhát Mountains.
One Palaeolithic settlement in the discussed area with published archaeological material is the Legénd-Káldy-tanya complex (Markó-Péntek 2003-2004). The assemblage contains 1006 chipped stone artefacts. In the raw material usage the hydrothermal or limnic raw materials ("limnic silicites", Přichystal 2010) dominate the assemblage with more than three quarters of the total (76.34 \%). A relatively small amount (6.34 \% of the total) could be regarded as local from the environs of Galgagyörk and Püspökhatvan, about 20-25 km from the site (Cs. Balogh-Dobosi 1995; Markó 2005). A somewhat bigger part (17.23\% of the total) with a very characteristic yellowish white, whitish yellow, or reddish patina originates from the hydrothermal outcrops of the Mátra Mountains $(45-50 \mathrm{~km}$ as the crow flies to the East of the 
site). The geological source of the majority of the limnic silicites could not be identified exactly. A possible provenance from Central Slovakia can not be excluded. In Central Slovakia the nearest primary limnic silicite outcrops are situated in the Žiar-Basin, along the Hron (Garam) River, in the environs of Stará Kremnička, Lurila, Slaská villages. They are characterized by vegetal and pollen remains. Typically, they have a great variability of colours, with prevailing light, white, greyish-black and black colours. The artefacts made of these variants of limnic silicites have a very intense patina (Kaminská 2001: 84; Kaminská 2013: 100). In the Legénd-Rovnya site (Péntek-Zandler 2013b), there is a flake core with greyish-white stripes. At Hont-Csitár (Zandler 2010) and Hont-Babat (Zandler 2012a), there are also some pieces stemming likely from those outcrops in Central Slovakia. Of these sites more anon in this paper.

The extralocal felsitic porphyry (metarhyolite) from a source $110 \mathrm{~km}$ away in the Bükk Mountains, is the second most abundant raw material assortment on the site (18.49 $\%)$. Some years ago a PGAA analysis was carried out with positive results on some archaeological samples of the Cserhát Mountains too (Markó et al. 2003: 297-314). The presence of all known obsidian variants at the site should be stressed. Even the very rare „red” or mahogany variant is present (Bíró et al. 2005: 94, Fig. 3.3). The raw material use of the Legénd-Káldy-tanya complex can be compared with the data on the raw material circulation during the Middle Palaeolithic in Northern Hungary (Markó 2009a).

In the tool type composition of the raw materials the limnic silicite dominates with 36 pieces, followed by the felsitic porphyry with 22 pieces out of the 67 tools.

The tool types have a very broad spectrum. Among the tools, those of Middle Palaeolithic character, such as leafpoints, bifaces and side-scrapers dominate. There are some typical Micoquian tools like Bocksteinmesser, Faustkeilblatt, groszak (Typ Heidenschmiede, Bosinski 1967: 33). The endscrapers have no Upper Palaeolithic affinity at all. The lateral edges of the bifacial tools were worked with the WGKmethod (wechselseitig-gleichgerichtete Kantenbearbeitung, Bosinski 1967: 43). The assemblage could be connected to the Bábonyian industry (Ringer 1983) which has a very close relation to the Central European Micoquian (Bosinski 1967) or Keilmessergruppe (Mania 1990: 145; Veil et al. 1994: 40; Bosinski 2000-2001: 112; Conard-Fischer 2000: 11-12).

\section{The site complex and its surroundings}

The sites belonging to the interpreted site complex are located on both sides of the Halyagos Streamlet which is a tributary of the Galga River. The valley of the streamlet is a so-called pseudo "dead end valley". This phenomenon is well known in the Cserhát Mountains, where the most Middle Palaeolithic and Early Upper Palaeolithic sites are lying along or at the heads of "dead end valleys". Without striving to completeness we could mention some characteristic examples like Vanyarc-Szlovácka-dolina, the eponym site of the "Vanyarc-type" industry (Markó 2007; 2012),

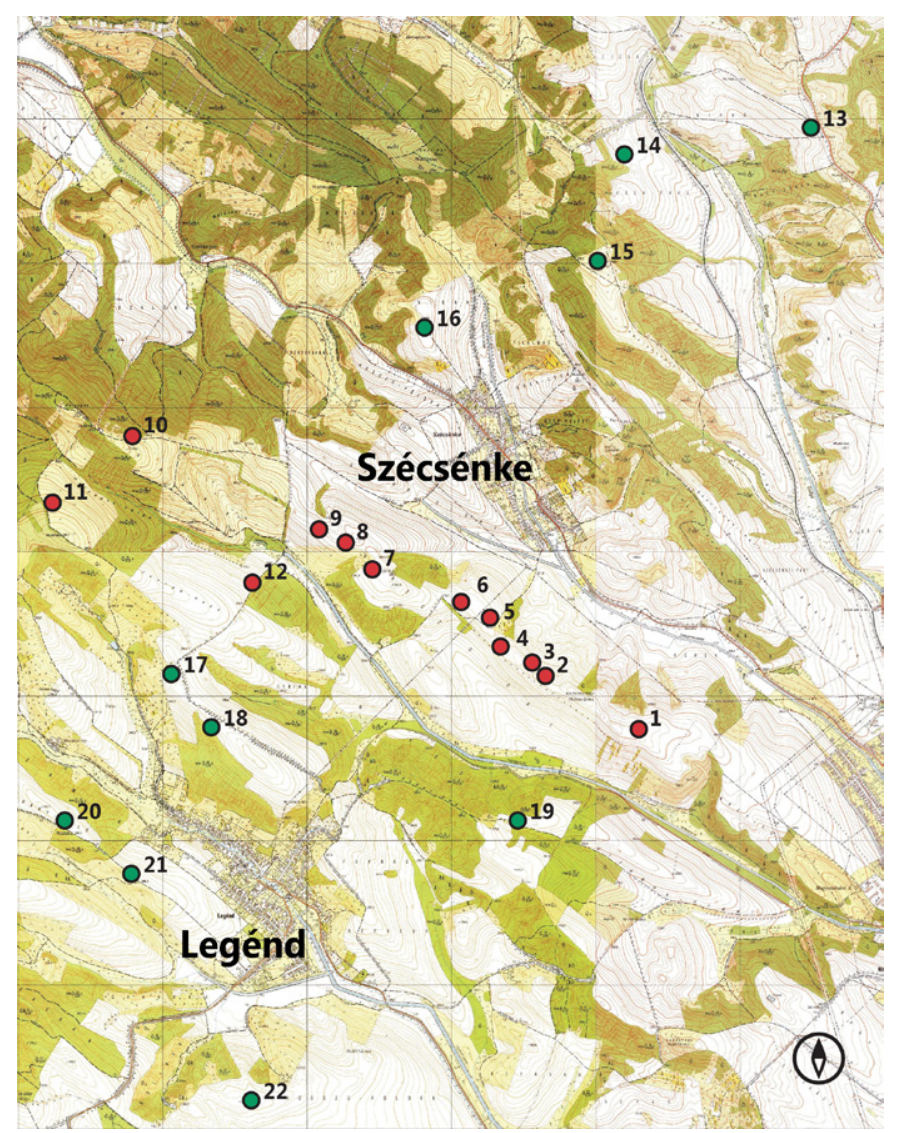

Figure 1. The Szécsénke site-complex (1-12) and its environment (13-22). // 1. ábra. Szécsénke lelőhelykomplexum (1-12) és környezete (13-22).

1: Szécsénke-Kis-Ferenc-hegy, 2-3: Szécsénke-Berecz-oldal-1, 4: Szécsénke-Berecz-oldal-2E, 5: Szécsénke-Berecz-oldal-2W, 6: Szécsénke-Berecz-oldal-3, 7-9: Szécsénke-Berecz-oldal-4, 10: Kétbodony-Halyagos-hegy, 11: Legénd-Rovnya, 12: Legénd-88, 13: Becske-Júlia-major, 14: Becske-4, 15: Becske-Büdös-tó-hegy, 16: Szécsénke-Visak, 17: Legénd-Káldy-tanya-1-3, 18: Legénd-Káldytanya-5, 19: Legénd-Pápai-hegy, 20: Legénd-Gubány-dűlő (Menyecskés), 21: Legénd-Gubány-dűlő, 22: Legénd-Hosszú-földek.

Debercsény-Mogyorós, belonging to the Moravian Szeletian (Markó 2009b). The same or very similar situation can be observed at the site of Hont-Csitár in the Ipoly Valley, belonging to the Szeletian of Moravian type (Zandler 2010) and at Demjén-Szőlő-hegy by Eger, with some Aurignacian characteristic (Zandler 2012b: 23). Presumably the choice of these topographical situations must have had a deliberate practical reason. Such dead-end valleys are very suitable to the „head-'em-off-at-the-pass” hunting strategy of reindeers (Baales 1999; Baang-Andersen 2008). Since they were not able to follow the herds directly (Burch 1972), hunters located their camps near valley bottlenecks. One hunter group drove the animals into the bottleneck where an other group were already waiting. The hunters were thus enabled to kill a large number of animals in a short time. The exhausted supplies could be restocked and the hunters and their families moved on.

In a distance of about $10 \mathrm{~km}$ westward from the Galga River there is the wide valley of the Lókos Streamlet. The Romhány Basin (valley-dilation, Láng 1967: 59) and the Lókos Valley divide the Cserhát Mountains and the Börzsöny Mountains. During the prehistoric times this valley 




Figure 2. The Szécsénke site-complex and its environment

The green circle on the right side of the map denotes the Szécsénke-Kis-Ferenc-hegy site, the red circles indicate the other sites belonging to the site complex. The purple circle denotes the Legénd-Káldy-tanya site and the yellow ones indicate Palaeolithic sites with bifacial tools, not discussed in this paper. //

2. ábra. A Szécsénke lelőhelykomplexum és környezete. A jobb oldali nagy zöld kör jelöli Szécsénke-Kis-Ferenc-hegy lelőhelyet, a vörös körök pedig a komplexumhoz tartozó többi lelőhelyet. A lila kör Legénd-Káldy-tanya lelőhelyet jelöli, a sárga körök a cikkben nem tárgyalt paleolitikus korú lelőhelyek bifaciális eszközökkel.

had to play a great role in migration, since it is located on a NW-SE oriented axis connecting the sites of the Southern Cserhát and the Galga Valley to those of the Ipoly Valley. Actually both sides of the Ipoly River and the environs of the village Hont in the Ipoly Valley are very rich in Palaeolithic settlements. Recently in connection with the RomhányDiós-út site, Viola T. Dobosi dealed with the importance of the Romhány or Nógrád Basin (Dobosi 2011).

Running directly south of Szécsénke, there was a main migration corridor connecting the Galga Valley and the Romhány Basin. The pseudo "dead end valley" of the Halyagos Streamlet represents an alternative route.

On Fig. 1. the Palaeolithic sites of the surrounding area can be seen. The central part of this area, with the discussed sites of the site complex is enlarged on Fig. 2. The green circle on the right side of the map denotes the Kis-Ferenc-hegy site, red circles indicate the other sites belonging to the site complex. The purple circle denotes the above mentioned Legénd-Káldy-tanya site and the yellow ones indicate Palaeolithic sites with bifacial tools, not discussed in this paper.

In the formation of the surface of the Cserhát Mountains young tectonic movements played a dominant role, the valleys of the discussed area are all forecasted tectonic erosion-valleys. These valleys have asymmetric cross-sections, where the two sides are characterized by differing slope angles and rock exposures. One side of the slope is gentle and covered with thick loess-like soil. This soil and the underlying rock allochtonously could drag even under the level of the alluvia. In contrast, the other slope bordering the valley is steep, loess-like soil does not occur and either the rocks of the overlying mountain belt or the eruptive ones emerge. The steep slope means abrasion, destruction and transportation of the surface of the earth. The assumption that these steep valleys had been formed due to glacial solifluction, gelisolifluction contradicts the fact that they were formed partly due to recent tectonic movements. However not only with south-facing sloping but rather equally, they occur with the most differing exposition, while in a case of glacial solifluction, gelisolifluction the south-facing sloping would be the most frequent.

The Berecz-oldal is an about $3.5 \mathrm{~km}$ long steep, ascending hillside, located on the northern side of the Halyagos Valley. At the upper verge of the hillside there is a relatively flat plateau of 50-150 m width, where the Palaeolithic sites or find concentrations occur. The other, northern slope to the valley of the Szécsénke Streamlet is rather moderate.

\subsection{The Szécsénke-Kis-Ferenc-hegy site}

The site with the richest archaeological material of the site complex is the Kis-Ferenc-hegy (KFH) site. It is lying on the plateau of about $250 \times 200 \mathrm{~m}$ area on the asymmetrical hill-comb, located between the valleys of the Szécsénke and Halyagos streamlets at an altitude of 265-270 m a.s.l.. Its relative altitude is $70 \mathrm{~m}$ from both valley floors. In the southwest corner of the site there is an approximately $50 \times 50 \mathrm{~m}$ gravel bed. Its geological age is Upper Oligocene Chattian Stage, belonging either to the Budafok Sand Formation (Hámor 1985: 234) or the Pétervására Sandstone (Korpás 1988: 64-66). It consists of quartzite pebbles, diverse siliceous pebbles (hereafter shortly silex), radiolarite pebbles, hydrothermal chunks, petrified woods and can be regarded as a potential raw material source. The chipped stone assemblage processed so far by the authors from the site contains 1084 lithic artefacts (Péntek-Zandler 2013a).

\subsubsection{The raw materials in the archaeological assemblage}

The most dominant raw material is limnic silicite with 466 pieces ( $42.44 \%$ of the total), but its ratio is substantially lower among tools: with 21 pieces it amounts to only 17.65 $\%$. Thanks to the Miocene postvolcanic activity this raw material is very common in the Cserhát Mountains. The limnic silicite originates from the hydro- or limnic quartzite banks in the vicinity of Galgagyörk or Püspökhatvan. Two raw materials, silex and quartzite, could be regarded as local. We use the term silex as general and not as a petrographic term as the distinction between the diverse types of siliceous pebbles is very problematic. This raw material category contains a kind of porous silicified volcanic rock of yellowish colour, which is manifested in pebble form. The ratio of silex with 185 pieces is $17.07 \%$ in the total assemblage but it is significantly higher among tools (37 pieces, 
$31.09 \%)$. The ratio of the 9 quartzite pieces in the total assemblage is only $0.83 \%$, but there are three notched tools made of this material. Quartzite is a common raw material at archaeological sites in the Cserhát Mountains. Based on our observations, it is mainly related to Middle Palaeolithic or Early Upper Palaeolithic sites. However, recently clean-cut traces of intensive quartzite usage were found at Csővár-Arany-hegy in a Gravettian assemblage and at the Aurignacian site Legénd-Hosszú-földek (Péntek 2015b). According to K. Valoch it is the characteristic raw material of the so-called „Begleitindustrie“ (collateral industry) at some Moravian and Slovakian Szeletian sites (Valoch 1955: 28-32). In relation to the quartzite or quartz it is worth mentioning the Bavarian Szeletian site Zeitlarn. There is no concordance in the judgement of cultural affiliation of the site. In T. Hopkinson's view the end-scrapers at Zeitlarn "are made on ,broad blades" or flakes and are closely similar to pieces from the Miqoquian of the Sesselfelsgrotte some $30 \mathrm{~km}$ to the west and described by Richter [1997] as ,mikrokratzer". (Hopkinson 2006: 232). In the relatively small excavated assemblage there are surprisingly many crystalline quartz (kristalliner Quarz), 23 pieces which is 19.7 \% of the total (Heinen-Beck 1997: 77). The only long distance raw material, the „Szeletian felsitic porphyry" (metarhyolite) is represented by 412 pieces, with an extraordinary high ratio of $38.01 \%$. A raw material of uncertain provenience is the radiolarite, it is represented in the assemblage by 18 pieces (1.66 \%). With the naked eyes it is very similar to the Carpathian radiolarite, however radiolarite was also described in pebble form at the east side of the Börzsöny Mountains in the so-called Nagyoroszi Pebble Formation (Gyalog-Budai 2002: 220). Moreever, actually all potential raw material sources in the Cserhát Mountains, pebble outcrops or gravel beds contain some radiolarite pebbles of good knapping quality.

\subsubsection{The archaeological assemblage}

The Palaeolithic industry is a typical flake-industry, no laminarity could be observed. Detailed technological analysis has not been carried out so far, we have no concrete theory about the applied debitage, but there are no traces of the Levallois-debitage. The debitage-material represents 86.81 $\%$ of the total assemblage: The ratio of the flakes greater than $15 \mathrm{~mm}$ including the elongated, "blade-like" flakes (13 pieces) is $31.20 \%$, that of the flakes less than $15 \mathrm{~mm}$ is 55.81 $\%$. Among the flakes they are mainly flakes that originated from the shaping and preparation of the cores and from tool making and retouching. Among the flakes no raw material preference could be observed. Traces of Upper Palaeolithic blade technology are scarce, there are only 3 tools made on blades or on "blade-like" blanks: two high end-scrapers of definite Aurignacian character, made of silex and a leafpoint made of limnic silicite of which more anon.

In the assemblage collected from the surface there are 119 formal tools belonging to the Palaeolithic industry. Most of the tools are made of felsitic porphyry (53 pieces, $44.54 \%$ ), followed by silex (37 pieces, $31.09 \%$ ), limnic silicite (21 pieces, $17.65 \%$ ), radiolarite (5 pieces, $4.20 \%$ ) and quartzite (3 pieces, $2.52 \%)$. Among the Palaeolithic formal tools we distinguished 5 fundamental tool categories.
There are altogether 34 pieces of flake end-scrapers (28.57 $\%)$. There is a great dual raw material preference, 14 pieces were made of silex, 13 pieces of felsitic porphyry, 5 pieces of limnic silicite and 2 pieces of radiolarite. The end-scrapers have a very varied morphology. Besides the circular ones there are atypical nosed end-scrapers, carinated (keeled) pieces (grattoir caréné) and particularly fan-shaped forms with narrow base too. Among the Upper Palaeolithic types (carinated end-scrapers, Aurignacian-like high end-scrapers) there are no pieces made of felsitic porphyry. The base of some pieces seems to be intentionally broken, perhaps because of hafting purpose. In these cases there is a slightly acute angled break surface and a lip on the lower edge (Jennings 2011: 3646, 3650). In the case of felsitic porphyry the base of the tool is sometimes the naturally cleavage surface along a diaclase or joint. A joint is a natural fracture in the continuity of either a layer or body of rock that lacks any visible or measurable movement parallel to the surface (plane) of the fracture.

There are pieces with retouched lateral edge(s). As a matter of fact these tools are combination tools of an end-scraper and a side-scraper. This phenomenon was mentioned by K. Valoch in relation to the archaic lithic material of Jezeřany I. and II (Valoch 1966: 14). This could also be found at other Moravian Szeletian sites as for example Trboušany (Hladíková 2002: 77, Obr. 8:7), Neslovice (Valoch 1973: 13, Tab. I/2,4), Vedrovice V (Valoch 1993: 35, Abb. 14:12; 49, Abb. 28:1), Vincencov (Svoboda-Přichystal 1987: 10, Tab. I.: 5), Želešice III (Škrdla et al. 2014: 92, Fig. 12:13, 98, Fig. 12: 13, 15, 16) and even in Bavaria at Zeitlarn (Heinen-Beck 1997: 84, Abb. 7:5,6). Most end-scrapers show partial ventral thinning or retouch, or at least the bulb is eliminated. This attribute is well known in the Moravian or Bavarian Szeletian, for example Trboušany (Hladíková 2002: 78, Obr. 9:3,4,7) and in Zeitlarn (Schönweiss-Werner 1986: 10, Abb. 3:8; Heinen-Beck 1997:84, Abb. 7:5,6). Ventral thinning could be associated in the Cserhát Mountains mainly with Micoquian-Bábonyian assemblages, for example at Galgagyörk-Csonkás-hegy (Markó et al. 2002: 249, Fig 2.1, 2.4) and Legénd-Káldy-tanya (Markó-Péntek 2003-2004: 169, Fig. 4.7). M. Oliva in his paper dealing with the industries of Jezeřany suggests that the ventral retouching is in some way genetically related to leaf points (Oliva 1979: 47).

On the base of a piece made of felsitic porphyry a Clactonian notch could be found similar to pieces occurring in Zeitlarn (Heinen-Beck 1997: 84, Abb. 7:6). There is an atypical nosed end-scraper made of felsitic porphyry. Analogous pieces could be found in Vedrovice V (Valoch 1993: 35, Abb. 14:2,3), Vincencov (Svoboda-Přichystal 1987: 10, Tab. I:1) or even in Zeitlarn (Schönweiss-Werner 1986: 10, Abb. 3:4-6).

It is noteworthy to mention the carinated end-scraper made of silicified volcanic rock (Fig. 3.1). Both lateral edges are retouched, the base has a narrow fan-tail like shape and is thinned on the ventral face. As a matter of fact it is a combination of a double side-scraper and an end-scraper. Typological resemblances are found in Moravia, for example at Ondratice (Oliva 1992: 51, Fig.5). 


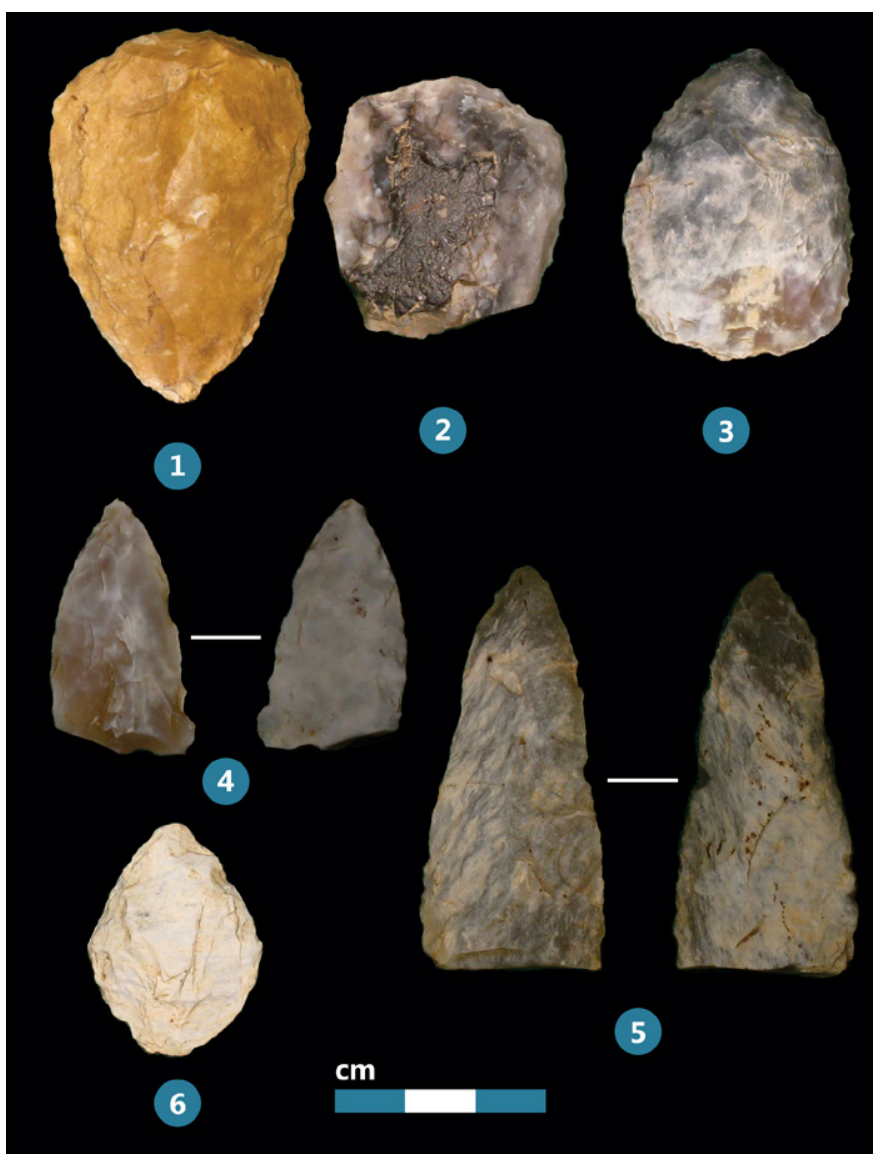

Figure 3. Selected tools from the Szécsénke Kis-Ferenc-hegy site. 1-3: end-scrapers made on flakes, 4: "pointe à face plane"-like leaf-point; 5-6: leaf-points (1-3: siliceous pebble, 4: limnic silicite of Cserhát Mts., 5-6: felsitic porphyry). //

3. ábra. Eszközök Szécsénke-Kis-Ferenc-hegyről. 1-3: szilánkkaparók, 4: "pointe à face plane"-szerủ levélhegy; 5-6: levélhegyek (1-3: kovakavics, 4: cserháti limnoszilicit, 5-6: kvarcporfír).

The tool category of the leaf-shaped tools consists of 20 pieces $(16.81 \%)$. There is a definitive raw material preference, 13 pieces are made of felsitic porphyry, 5 pieces of silex and 2 pieces of limnic silicite. Most of the tools are symmetric or perhaps slightly asymmetric to the longitudinal axis, that is, all these pieces could be interpreted as leaf-points. Morphologically the pieces show a highly variable picture. K. Valoch in 1960 discussed this question in much detail (Valoch 1960: 30-31). He stated that it is very rare if on a site only one form of leaf-shaped tools can be found (e.g. Moravany-Dlhá). In Moravia it is much more frequent that a variety of leaf-shaped tool shapes occur at the same site (Ořechov I, II; Modřice; Neslovice).

In the assemblage there are pieces with biconvex, planoconvex and parallelogramm cross sections. Nine pieces are broken fragments with an average length of 15-25 mm and we can determine with great probability that they are all base fragments. There is a piece with a notch at the base, maybe because of hafting. Very characteristic are some pieces with a relative short, wide and massive form.

The above mentioned piece made of a „blade-like” blank is plano-convex. On the ventral side only the edges are retouched (Fig. 3.4). Similar pointe à face plane leaf-points occur in the assemblage of Ondratice (Valoch 1967: 13, Tab. V/1; 21, X/1; 28, XIV/1), Neslovice (Valoch 1973: 17, Tab. V/6;
28, XVI/2) and Jezeřany (Oliva 1979: 48 and Taf. II/9) either as parallel phenomenon or as an influence of the Jerzmanowician industry, postulated by Chmielewski (1961). At the Moravian Szeletian site Želešice III both the unstratified surface collection and the excavated material yielded characteristic Jerzmanowice-type points. But only the surface collection contains leaf-points (Škrdla et al. 2014: 98-99, Fig. 12). The Jerzmanowice-type points are present at Vedrovice V (Valoch 1993: 45, Abb. 24:5, Abb. 25:3) and at the surface site Bratčice I where the raw material distribution and techno-typological point of view is very similar to Želešice III (Škrdla et al. 2014: 99). According to P. Škrdla et al., the most important feature of the Moravian Szeletian is the presence of the Jerzmanowice-type points which is regarded as type artefact of the Lincombian-Ranisian-Jerzmanowician technocomplex (Flas 2006; 2011).

A general characteristic is the so-called WGK-method which is a typical attribute of the late Middle Palaeolithic Micoquian industry. According to the authors the WGK is present in the Bábonyian-Szeletian technocomplex (Ringer-Mester 2000: 267-268). Zs. Mester carried out a detailed morphometrical analysis on the leaf-shaped tools of the Jankovichian and Szeletian industries. He concluded that the façonnage alterne, which in his opinion more or less corresponds to the WGK-method, is without doubt present in the production of the leaf-shaped tools of the Szeleta Cave (Mester 2008-2009: 91). In another paper, dealing with the leaf-points of the Szeleta Cave, Zs. Mester defines the alternate shaping of the edges as a two-step method: "the first step is a series of removal along the edge on one face (dorsal or ventral) and second is the same operation on the other face." (Mester 2010: 110). This defined method could be correlated with the WGK-method. After a well-founded morphometrical analysis and comparing the Early Szeletian bifacial point features to the Jankovich Cave bifacial tools, he came to the conclusion that: "on the basis of the lithic technology of bifacial tools that the Jankovichian and the Early Szeletian belong to the same archaeological culture, and there is no provable relation on technological ground between the Early and Developed Szeletian" (Mester 2010: 121).

The tipped distal fragment made of felsitic porphyry with the narrow, slender, elongated form and plano-convex cross section is the biggest $((57) \times 26 \times 12 \mathrm{~mm})$ leaf-point fragment in the assemblage. (Fig. 3.5).

There are 23 pieces (19.33\%) in the category of the sidescrapers. There is a very pronounced raw material preference, 13 pieces are made of felsitic porphyry, 5 pieces of silex, 4 pieces of local limnic silicite and only one piece of Carpathian radiolarite. Morphologically they are highly variable, most of the pieces are simple straight or convex side-scrapers but there are convergent or transversal pieces too. Especially the pieces made of felsitic porphyry are relatively small in dimensions. The obvious reason could have been the saving, economizing housekeeping with this long distance raw material.

In the Crimea most of the Kiik-Koba facies sites „may represent palimpsests where the distance from raw material 
encouraged the reuse and extensive rejuvenation of tools, resulting in high percentages of tools with multiple-retouched edges and overall small size." (Marks-Chabai 2001: 194).

At some pieces the elimination of the bulb could be observed. There are two natural backed pieces (racloir à dos naturel). K. Valoch mentioned the existence of such pieces from the archaic material of Jezeřany I. and II. (Valoch 1966: 38, Fig. XIX/4; 43, XXII/3).

On the Fig. 4.1 there is a side-scraper of small dimensions is made of Carpathian radiolarite. The $31 \times 21 \times 5 \mathrm{~mm}$ tool has a subtriangular form and its right edge is bifacially retouched. On the Fig. 3.2 a double or convergent side-scraper made of local silex can be seen. The dorsal face is finely elaborated in an invasive manner. The proximal end is thinned from the ventral face, the butt is prepared. Dimensions: $46 \times 34 \times 12$ $\mathrm{mm}$.

There are altogether 15 bifacial tools in the assemblage (12.61\%). This tool category contains the bifacially worked artefacts which are hardly, or because of their recent state (breakage, plough marks) not unambiguously classifiable. There are also pieces that were abandoned because of either technical knapping accident or other reasons, such as raw material flaws.

There is a fragment of a bifacial tool, which, due to its acute-angled subtriangular form after breakage, could function as a bifacial knife. On the hypotenuse of the triangle a special kind of detachment can be seen which suggests the so called Prqdnik-spall. O. Jöris in the Micoquian (Micoquo-Prondnikian) assemblage of the Bu-III layer of the Buhlen Cave in Germany could set apart some Praqdnik-Schaber (Jöris 2001: 32, Abb. 4.15; 4.16,1,3-5,7-11; 4.17,1-2). Bifacial knifes (Keilmesser) occur sporadically in the material of the archaic Moravian Szeletian sites, such as Jezeřany I. and II. too, where even the Prqdnik-technique is not unknown. In connection with Keilmesser he wrote: "an einigen Exemplaren beobachtet man Spuren der Prondnik-Technik (XI/1-3), die hier und da auch an Schabern zu sehen sind (XII/4)." (Oliva 1979: 48) (Fig. 4.2).

The last tool category of other tools or worked pieces contains 27 pieces altogether (22.69\%). Out of the most typical tools the following pieces could be emphasized:

1. Tranchets (chisels): 3 pieces (2.52\%). These are corelike fashioned chisel-like tools. Similar pieces could be found for example in Neslovice (kernförmig bearbeitete meißelartige Artefakte, Valoch 1973: 11 and Taf. XIII/2).

2. Notched tools: 4 pieces (3.36\%). Out of these, 2 pieces are made on massive quartzite flake with deep, unretouched Clactonian notches. J. W. P. van der Drift suggests that the deep hollow fracture, often called Clactonian notch is made in oblique bipolar technique by placing one contact point a small distance from the edge and another contact point at a greater distance from the edge. The reduction face of the struck stone shows a convex fracture between the impact popints, and the perpendicular direction this same fracture shows a deep concave surface (van der Drift 2009: 9 and Fig. 5G). Another two pieces are made of felsitic porphyry. One of the pieces

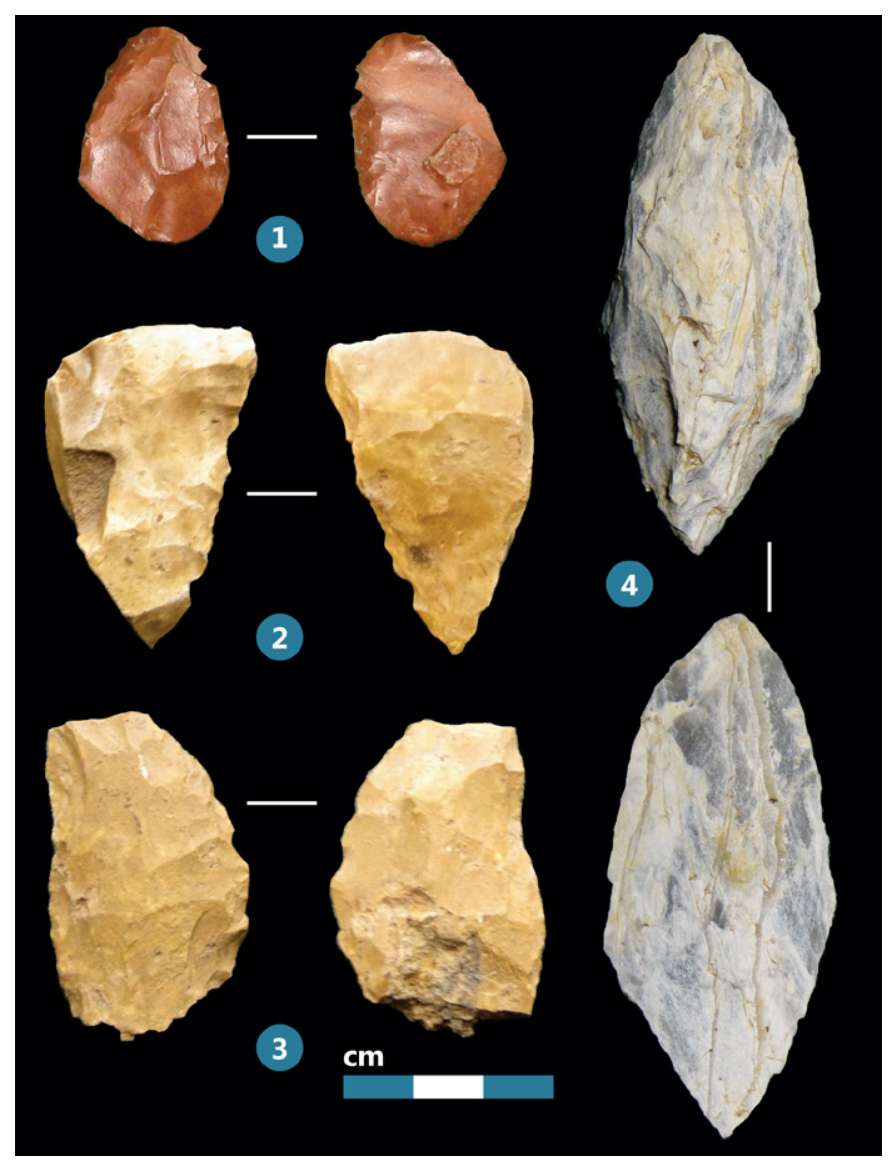

Figure 4. Selected tools from the Szécsénke Kis-Ferenc-hegy site. 1: side-scraper, 2-3: bifacial tools, 4: limace (1: Carpathian radiolarite, 2-3: siliceous pebble, 4: felsitic porphyry). //

4. ábra. Eszközök Szécsénke-Kis-Ferenc-hegyről. 1: kaparó, 2-3: bifaciális eszközök, 4: limace (1: kárpáti radiolarit, 2-3: kovakavics, 4: kvarcporfír).

is actually a combined tool, on the left edge there is a notch, on the right edge two nose-like tips (micro borers) can be seen.

3. There is a splintered piece (pièce esquillée).

4. There is a borer made of quartzite.

5. Tools made on cores which was regarded by K. Valoch as a typical feature of the Moravian Szeletian (Valoch 1966: 24) are represented by a burin made of limnic silicite.

A very interesting and relatively rare tool in the Hungarian Palaeolithic is the limace made of felsitic pophyry. The ventral face of the tool (the natural cleavage surface of the raw material) is unworked, the dorsal face is rough-andready worked. On the right side of the dorsal face, a little recent damage can be seen. The tool has an approximately deltoid form and measures $76 \times 32 \times 12 \mathrm{~mm}$. With its morphometrical characteristics the tool resembles the 1B-type of Szeletian bifacial foliate tools, broad, elongated and symmetrical (laurel leaf shape) with pointed base (Mester 2010: 110; 2011: 25) (Fig. 4.4).

\subsubsection{Discussion of the KFH site}

In the assemblage, those typical to the Middle Palaeolithic (side-scrapers, bifacial tools) make up the $31.93 \%$ of the tools. Most of the end-scrapers have a rather archaic 
character, only some atypical pieces represent Upper Palaeolithic types. With the exception of the above mentioned core-burin, there are no burins and only one borer made of quartzite among the tools. The ratio of the leaf-shaped tools is high. The elaboration is sometimes relatively rudimentary, does not measure up to the refinement typical for the leaf-shaped tools of the Developed Szeletian. Among the other worked pieces the number of archaic tools, such as tranchets, notched tools made of quartzite, backed knifes is very significant. The industry is a typical flake-industry, the laminarity is anecdotical.

All tools have typological, morphological analogies in the Moravian or Bavarian industries with leaf-points, that have the general denomination of Szeletian industry since the fundamental paper written by F. Prošek (Prošek 1953). According to the original definition of Prošek, the Szeletian is characterized by the predominance of the leaf-shaped tools and side-scrapers, the Upper Palaeolithic tools play a subordinate role. End-scrapers occur relatively in force, burins only sporadically, backed pieces as good as never. Similar phenomena could be found notably in the Moravian archaeological materials originating from surface collections. Vedrovice $\mathrm{V}$ was the first site where traces of the Szeletian, as defined by Prosek, have been found at a greater area, under relatively undisturbed conditions (Valoch 1993). The investigations carried out by J. K. Kozłowski established the Interpleniglacial age of the site Dzierżysław in Southern Poland and affiliated its findings with the Szeletian of Moravian type (Bluszcz et al. 1994).Zeitlarn, a site that has been partially excavated, previously known only by surface collection, also belongs to this industry (Heinen-Beck 1997). Based on the fact that end-scrapers are made on "broad blades" or flakes and show closely similarity to pieces from the Micoquian of the Sesselfels Cave ("Mikrokratzer", Richter 1997), T. Hopkinson takes the attitude that there is no reason to attribute the assemblage of Zeitlarn to a "transitional industry" (Hopkinson 2004: 232). In Austria only several single occurences of leaf-points are reported (Trnka 1990; Nigst 2006). The leaf-point at Schletz (Lower Austria) came to light under stratified conditions, but as an isolated find without any accompying artefacts, so its cultural association is problematic. Hitherto in Austria there is only one significant Micoquian assemblage in the Gudenus Cave (Derndarsky 2001).

M. Oliva published the list of the Bordes-indices for 13 Moravian Szeletian sites (Oliva 1995: 90). The list is primarily based on the evaluation of surface finds in which cases the possibility of some mixing with other industries (Micoquian, Bohunician, Aurignacian) could not be excluded. Though the tool composition of a stone industry is determined by several circumstances (for example climatic, faunistic and even general way-of-living circumstances), the index values with a relatively great deviation are referring perhaps some sort of techno-typological development. M. Oliva made a techno-typological revision on the chipped stone assemblage of Jezeřany. The conclusion of this revision and new evaluation is noteworthy to cite word-forword: „Die Bearbeitung des neueren und reichen Sammelgutes aus Jezeřany hat erwiesen, daß seine Micoquien-Komponente wesentlich stärker ist als die erste Veröffentlichung annehmen ließ (Valoch 1966). Man kann deshalb die ganze Kollektion im großen und ganzen dem mittelpaläolithischen Micoquien vom Typ Rörshain gleichsetzen. Die Jezeřany-Industrie unterscheidet sich von diesem Typ allerdings durch das Vorkommen einiger älterer Micoque-Elemente (Keilchen, Prondnik-Technik), durch die Menge von Geröllgeräten und die Anwesenheit jungpaläolithischer Typen." (Oliva 1979: 54).

It is very instructive to set the above idea agains the opinion of Z. Nerudová about the collection of Jezeřany and its relation to Micoquian: “Les similarités dans l'économie des matières premières et dans le débitage, la présence des nucléus dicoïdes et enfin la similitude de la typologie et technologie signalent la parenté du Szélétien archaïque de Jezeřany I avec le Micoquien de Bořitov V et de Kůlna, couche 6a." (Nerudová 1996: 36).

In a relatively recent paper Nerudová analysed the Moravian Szeletian lithic industry from a technological point of view. On the basis of this analysis it could be stated that ,the Moravian Szeletian is a dynamicly developing culture, which is influenced by the Micoquian, in its initial phase, interacts with the Bohunician in its middle phase, and ends as the advanced Szeletian touched by the Aurignacian. The oldest Szeletian collections are non-blade and non-Levallois ones represented by sites Vedrovice V, Jezeřany I and Moravský Krumlov IV-3." (Nerudová 2008-2009: 56).

From the assemblage of Jezeřany, regarded to be nearly related to the Micoquian, to the younger („more developed”) sites, the ratio of the end-scrapers and in general, of the Upper Palaeolithic components (burins, borers) gradually increases and at the same time the ratio of the side-scrapers, bifacial and leaf-shaped tools decreases. In our opinion the Szécsénke-Kis-Ferenc-hegy site fit well in this trend and could be regarded as belonging to a relatively early phase of the Szeletian industry of Moravian type.

\subsubsection{Connections in Hungary}

To make a comparison with other assemblages from Hungarian open-air sites, there is one salient example, Hont-Csitár in the Ipoly Valley, where the Gábori couple excavated a somewhat mixed, inhomogeneous Palaeolithic material mainly of Middle and Upper Palaeolithic character in 1969. Unfortunately, the field documentation is missing, therefore the assemblage lost heavily from its information bearing significance. K. Zandler took up the challenge, since the new investigations in the Cserhát Mountains made it necessary to revisit and publish the excavated material of the site (Zandler 2010).

The revisited chipped stone assemblage contains 1581 pieces. At Hont-Csitár there is a very diverse raw material composition (17 different types), which is likely attributable to the mixed character of the assemblage. The limnic quartzite dominates both in the total (83.81\%) and among the tools (69.9\%). The ratio of the felsitic porphyry is 5.59 $\%$ of the total and $9.1 \%$ of the tools. Other raw materials play only a subordinate role. The local and regional raw 
materials originate from the Börzsöny and Cserhát Mountains. Quartzite pebbles occur on the banks of the nearby rivers and streamlets or in some gravel beds. Nummulitic chert is found in the Ipoly Valley, in South Slovakia and mainly in the Cserhát Mountains from where many gravel beds containing this raw material are known (MarkóKázmér 2004). The Carpathian radiolarite is known from the White Carpathians (Vlára River Basin, Cheben-Cheben 2010), from the Nagyoroszi Pebble Formation (Gyalog-Budai 2002: 220), and from Transdanubia. Opalites can be found in the Börzsöny or Mátra Mountains (Bíró 1986) and even in the environs of Eger (Kozłowski-Mester 2003-2004: 116).

The primary sources of extralocal raw materials like felsitic porphyry, jasper, lydite and hornstone are lying in the Mátra and Bükk Mountains (Dobosi 1978; Bíró 1984). There are both Carpathian 1 and 2 type obsidians from the Tokaj Mountains and Eastern Slovakia (Rosania et al. 2008 with further references). Finally there are some Northern flint pieces, perhaps erratic flint from the Upper Oder Basin or Jurassic flint from the Kraków-Częstochowa Plateau (Kozłowski 2013: 65) from at least $350 \mathrm{~km}$ distance as the crow flies.

Regarding lithic technology, it can be stated that the Levallois-technique is not representated and laminarity is relatively low. Tools made on blades come out at $10 \%$ of the whole collection. Cores are simple and less prepared. The WGK-method is present by the edge-elaboration of the bifacial tools.

The most important characteristic of the collection is the co-presence of Middle and Upper Palaeolithic tool types. Most of the Middle Palaeolithic tool types like side-scrapers, leaf-shaped tools are made of limnic quartzite and felsitic porphyry. Upper Palaeolithic tool types are made of limnic quartzite or radiolarite. The few tools made of Transdanubian radiolarite could be related to a younger Neolithic industry, possibly to the Zseliz or Lengyel culture. The most dominant tool types are different side-scrapers (20.45\%) and bifacially worked leaf-shaped tools (19.32\%). The shape of these latter tools is in general slightly asymmetric to the longitudinal axis. Among the end-scrapers there are some pieces made on blades and few Aurignacian types also can be observed. The occurrence of lateral edge retouch is rare.

K. Zandler came to the conclusion that the observed technology and tool type composition of the assemblage show evident similarity with the Bábonyian and Szeletian sites of the Bükk and Cserhát Mountains as well as the Moravian Szeletian sites. According to these similarities the HontCsitár assemblage could be placed in the Moravian Szeletian circle.

However there are some substantial differences between Hont-Csitár and Szécsénke-Kis-Ferenc-hegy. The collection of the KFH site seems to be very homogeneous, maybe that is why the raw material spectrum is much more steady. Local limnic silicite has a lower ratio both in the total and also among the tools. There are significantly more felsitic porphyry and siliceous pebbles both in the total collection and also among the tools. At the KFH site there is absolutely no laminarity, even elongated, „blade-like” flakes are very rare. In contrast, at Hont-Csitár the number of retouched blades is relatively high and there are many retouched flakes too. These do not necessarily belong to the Palaeolithic material with leaf-shaped tools. In the tool composition, thanks to this fact, the indices for the side-scrapers and leaf-shaped tools are actually lower. Regarding typology, in point of side-scrapers, leaf-points and bifacial tools there are no significant differences between the discussed assemblages. One important fact, which indicates a more archaic character of the KFH assemblage, is the form of the end-scrapers. The ratio of the Aurignacian-like end-scrapers is comparable, however at Hont-Csitár there are also end-scrapers made on blades.

Despite these discrepancies and differencies, the indices for the tool types of Hont-Csitár could be compared with the indices of the KFH site and even with the indices gained by M. Oliva for the Moravian Szeletian sites (Oliva 1995). On the basis of this comparison, the Hont-Csitár site could be connected to the younger or developed phase of the Szeletian industry of Moravian type.

\subsection{The Szécsénke-Berecz-oldal sites}

In northwestern direction about $500 \mathrm{~m}$ from the above reviewed KFH site four distinct find concentrations or sites of various sizes can be found. The distinction is not unconditionally theoretical, actually there are 20-30 m wide gaps without finds between the concentrations. The average thickness of the loess-like cover is $25-30 \mathrm{~cm}$. Below it there is a reddish-brown coloured paleo soil, from which the lithic artefacts come to light. The greater part of the area was for a long time uncultivated.

The first of the four sites, Szécsénke-Berecz-oldal BO-1 streches out on an elongated area of $250 \times 25-30 \mathrm{~m}$. Here, possibly due to ploughing activity two find concentrations were mixed together. Now it seems to be one and the same site, namely the chipped stone artefacts can be found fast continously, but there are two distinct, more dense spot at both ends of the site.

The small but characteristic assemblage consists of 122 artefacts. Amongst the raw materials local limnic silicite dominates, followed by silex. There are 8 tools in the assemblage, 3 of them are made of silex, 2 end-scrapers made on flake and a fragment of a leaf-point.

Three pieces, an end-scraper, a leaf-shaped tool and a sidescraper are made of limnic silicite of Mátra Mountains origin which has an anecdotical role in the total with a ratio of $7.38 \%$. These artefacts were carried to the site likely as finished tools. Two tools are made of felsitic porphyry, both pieces are leaf-points. The one piece is near symmetrical to the longitudinal axis. The longitudinal section (lateral view) is biconvex, the cross section is plano-convex. The shape of the tool is slightly deltoid (willow-leaf form) which is known from some unpublished Palaeolithic assemblages in the Cserhát Mountains and occur at numerous sites in the 




Figure 5. Selected tools from the Szécsénke Berecz-oldal BO-1 Palaeolithic site. 1: leaf-point, 2, 4: end-scrapers; 3: abandoned leafpoint (1: felsitic porphyry, 2: siliceous pebble, 3-4: limnic silicite of Mátra Mts.). //

5. ábra. Eszközök Szécsénke Berecz-oldal BO-1 paleolitikus lelőhelyről. 1: levélhegy, 2, 4: vakarók; 3: felhagyott levélhegy (1: kvarcporfír, 2: kovakavics, 3-4: mátrai limnoszilicit).

Moravian Szeletian. The edges are worked with WGK. Dimensions: $56 \times 30 \times 8 \mathrm{~mm}$ (Fig. 5.1). Another leaf-point made of limnic silicite of the Mátra Mountains is abandoned due to raw material flaws (Fig. 5.3). It is noteworthy to mention a quartzite flake core with traces of short hinge fracture scars (Fig. 17.1).

The Szécsénke-Berecz-oldal BO-2E (East) site streches out on an elongated area of $100 \times 25$ m directly over a ravine. There are 161 artefacts from this find concentration. The raw material composition is very heterogenous. Most of the pieces are made of local limnic silicite ( $52.17 \%$ ) but the role of silex is significantly higher as usual in the Cserhát Mountains (32.30\%). There are also 3 pieces made of nummulitic chert (Markó-Kázmér 2004). All other raw materials, such as quartzite, Mátra limnic silicite, Carpathian radiolarite, C1 type obsidian, Northern erratic flint are represented only by a few pieces. An artefact is made of a raw material which resembles lydite, perhaps also from the Mátra Mountains. There are altogether 14 tools in the assemblage, eight of them are end-scrapers made on flake, there is an end-scraper made on blade and five other worked tools, not exactly classifiable. Six tools are made of local limnic silicite, 4 pieces of silex, 1-1 pieces of nummulitic chert, quartzite, radiolarite and of an unidentified raw material. It is noteworthy

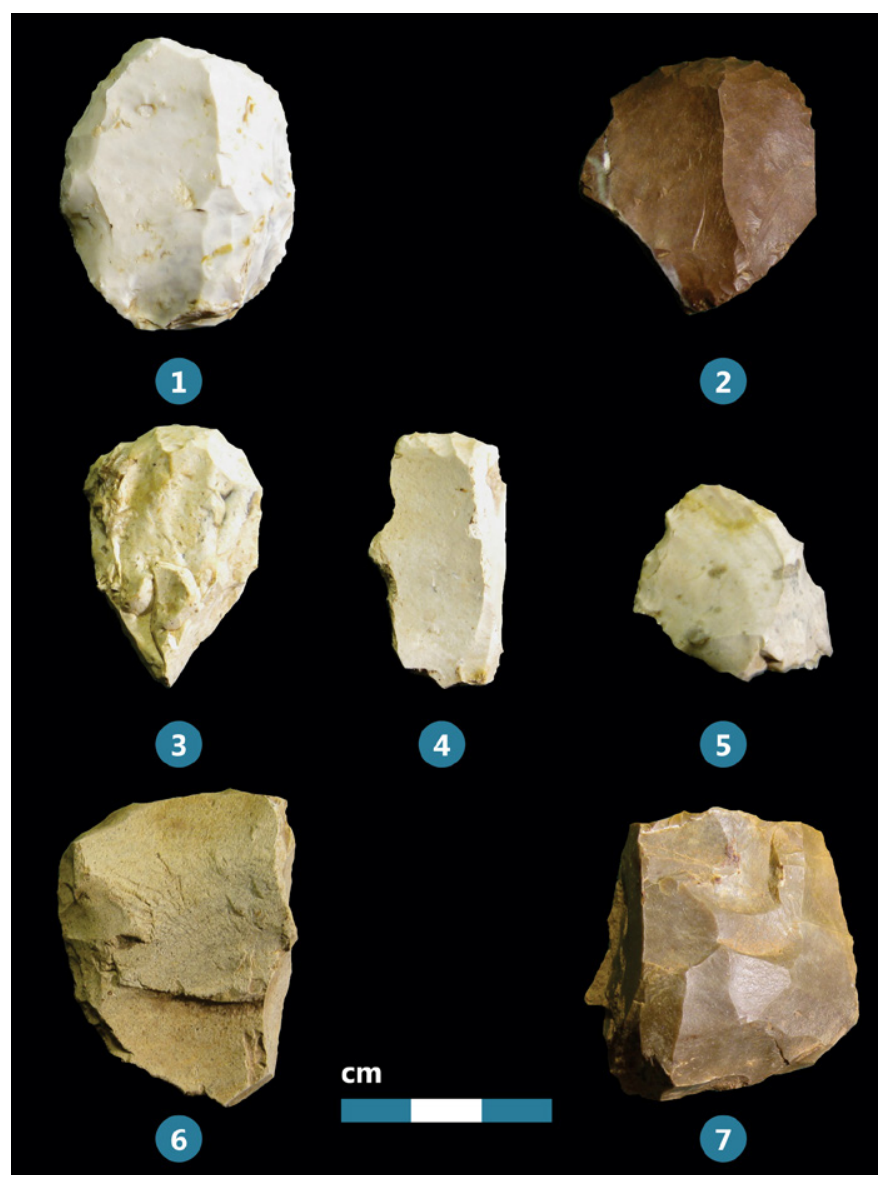

Figure 6. Selected artefacts from the Szécsénke Berecz-oldal BO-2E Palaeolithic site. 1-3: end-scrapers made on flakes, 4: end-scraper made on blade, 5-6: side-scrapers, 7: unipolar core (1,6: siliceous pebble, 2, 7: Carpathian radiolarite, 3-4: limnic silicite of Cserhát Mts., 5: limnic silicite of Mátra Mts.). //

6. ábra. Eszközök Szécsénke Berecz-oldal BO-2E paleolitikus lelőhelyről. 1-3: szilánkkaparók, 4: pengevakaró, 5-6: kaparók, 7: egy leválasztási felszínű magkő (1, 6: kovakavics, 2, 7: kárpáti radiolarit, 3-4: cserháti limnoszilicit, 5: mátrai limnoszilicit).

to mention three blades or "blade-like" flakes which are made of Mátra limnic silicite. A nicely elaborated end-scraper made on a slightly déjeté flake, made of Carpathian radiolarite has a very fine retouched half-steep convex working edge. Its butt is plain. Dimensions: $35 \times 37 \times 12 \mathrm{~mm}$ (Fig. 6.2). There is an unifacial, unipolar Carpathian radiolarite core with short flaking scars. Dimensions: $39 \times 38 \times 20$ mm (Fig. 6.7).

The Szécsénke-Berecz-oldal BO-2W (West) lies directly next to BO-2E and takes up a bigger area of 100×35-40 m. The assemblage consists of 262 artefacts. Among tools endscrapers have a great dominance (Fig. 7). Again, raw material utilization shows a heterogenous picture here. The local limnic silicite dominates evidently (56.49\%), followed by limnic silicite of Mátra Mountains origin (16.41\%) and local silex (12.98\%). There are some pieces of nummulitic chert, quartzite, Carpathian radiolarite, C2 type obsidian and felsitic porphyry. There are 22 tools, 11 end-scrapers made on flake, 4 end-scrapers made on blade, 1 side-scraper and 6 not classifiable worked pieces. Nine tools are made of local limnic silicite, 7 pieces of silex, 4 pieces of Mátra limnic silicite, 1-1 piece of radiolarite and felsitic porphyry. This latter tool is an end-scraper made on "blade-like" flake (éclat 


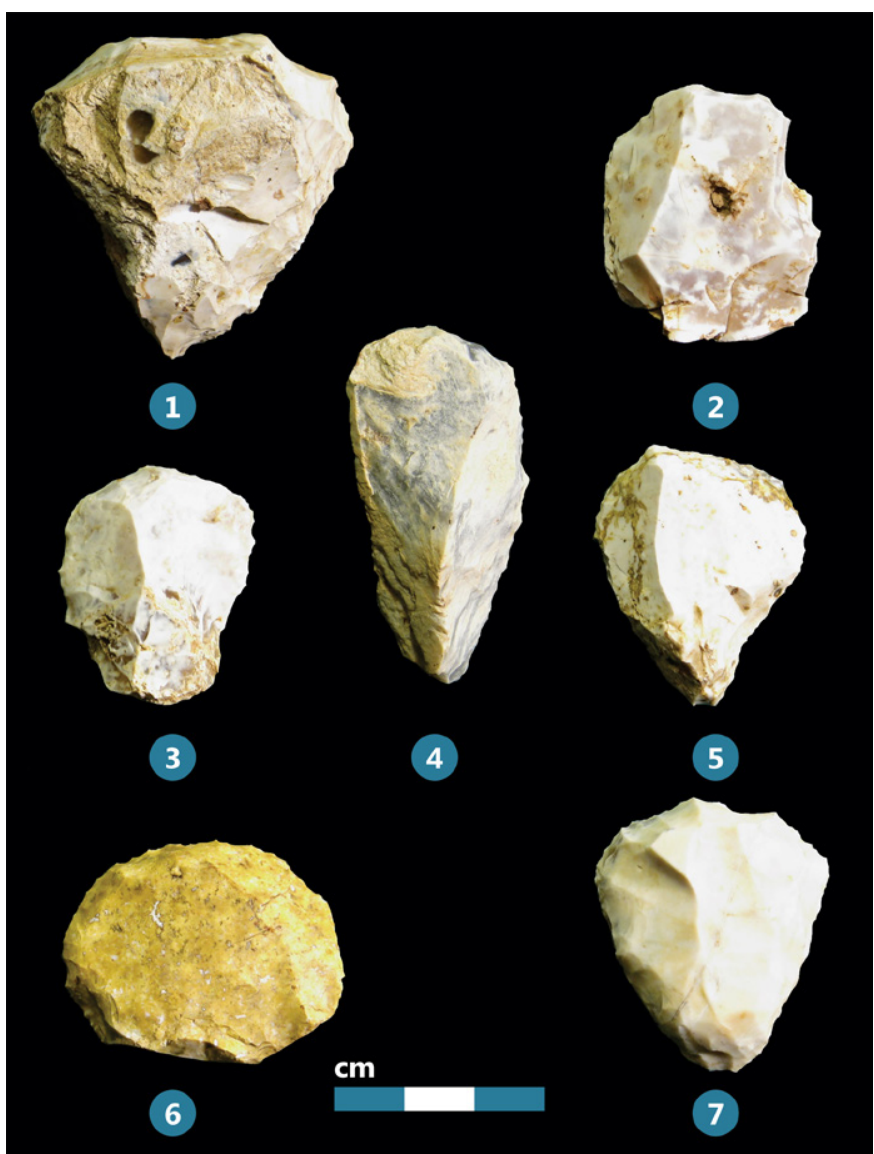

Figure 7. Selected tools from the Szécsénke Berecz-oldal BO-2W Palaeolithic site. 1-3, 5-7: end-scrapers made on flakes; 4: end-scraper made on a blade-like flake (éclat débordant) (1-3: limnic silicite of Cserhát Mts., 4: felsitic porphyry, 5-6: limnic silicite of Mátra Mts., 7: siliceous pebble). //

7. ábra. Eszközök Szécsénke Berecz-oldal BO-2W paleolitikus lelőhelyről. 1-3, 5-7: szilánkvakarók; 4: pengeszerủ szilánkon készült vakaró (éclat débordant) (1-3: cserháti Imnoszilicit, 4: kvarcporfír, 5-6: mátrai limnoszilicit, 7: kovakavics).

débordant, Fig. 7.4). Beyond tools 4 blades made of limnic silicite of Mátra Mountains origin are worth to mention.

The next site, Szécsénke-Berecz-oldal BO-3 streches out on an area of about $250 \times 50 \mathrm{~m}$. It has an assemblage of $633 \mathrm{ar}-$ tefacts. Beside the dominant local raw materials, limnic silicite (68.56 \%), silex (12.32 \%) there are nummulitic chert, quartzite, limnic silicite of Mátra Mountains origin, radiolarite, felsitic porphyry and a piece of vein quartz. Long-distance felsitic porphyry is relatively abundant with 48 pieces (7.58 \%). Among tools (33 pieces altogether), the 14 endscrapers made on flake dominate, there are 4 leaf-shaped tools, 3 side-scrapers, 1 bifacial tool and 11 other tools hardly classifiable. The silex raw material has a dominance with 15 tools, there are 9 tools made of local limnic silicite, 2 pieces made of Mátra limnic silicite, 3-3 pieces of radiolarit and felsitic porphyry and a little microlitic retouched quartz tool. The majority of the blades ( 5 of 8 pieces) are made of local limnic silicite.

On Fig. 9.4 a base fragment of a broken leaf-point made of local limnic silicite can be seen. The oblique fracture surface is heavily patinated, the breakage could have been a

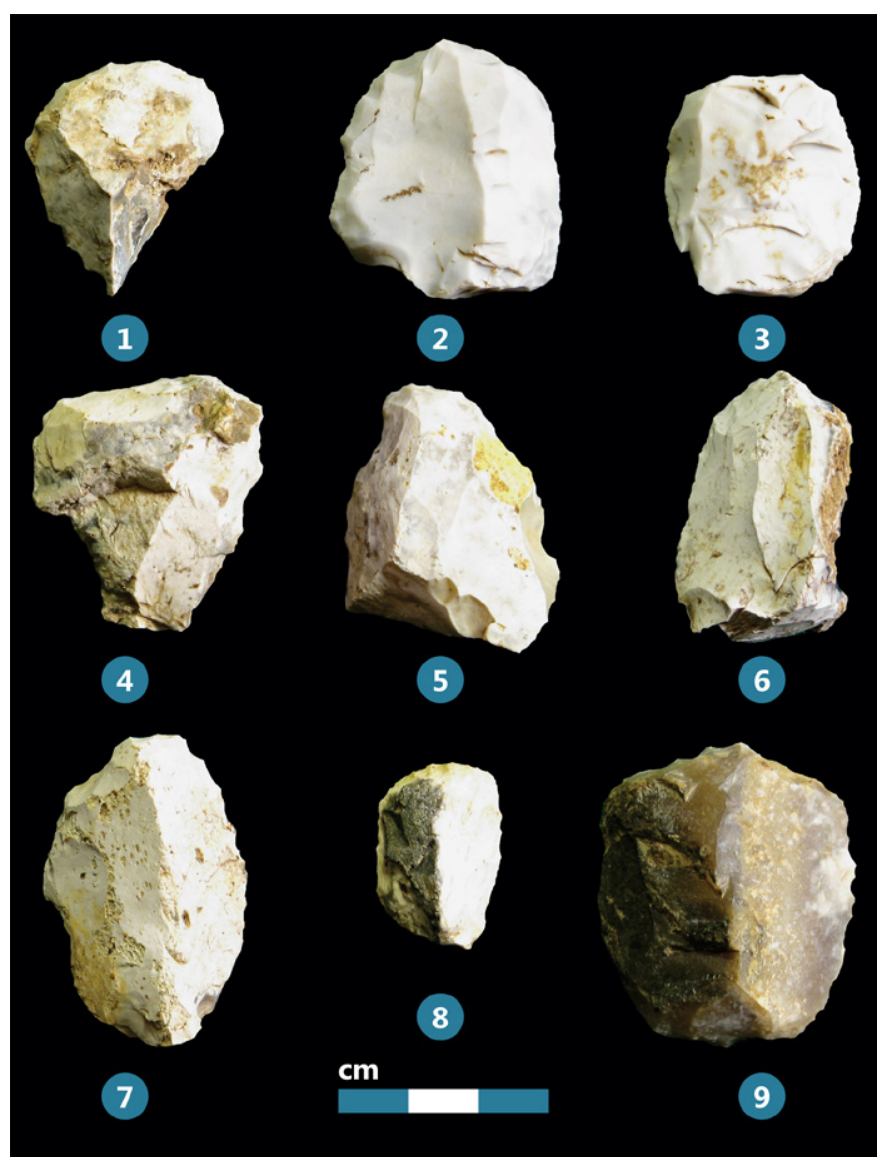

Figure 8. Selected tools from the Szécsénke Berecz-oldal BO-3 Palaeolithic site. 1-8: end-scrapers made on flakes (1-6: limnic silicite of Cserhát Mts., 7-8: siliceous pebble). //

8. ábra. Eszközök Szécsénke Berecz-oldal BO-3 paleolitikus lelőhelyről. 1-8: szilánkvakarók (1-6: cserháti limnoszilicit, 7-8: kovakavics).

knapping accident. The tip of the point is broken and patinated too. This tool has a clearly asymmetrical shape, its left lateral edge is slightly curved, the right one is rather straight. Both longitudinal and cross sections are plano-convex. The ventral face is thinned, both edges are retouched (WGK). Dimensions: $47 \times 34 \times 9 \mathrm{~mm}$.

The one side-scraper of great dimensions is made of felsitic porphyry. Its left edge is bifacially retouched, the right edge is retouched only from the ventral face. On the surface traces of a diaclase (yellowish spots) can be seen. Due to a large detachment in the middle of the ventral face the tool has a slightly concavo-convex profile. Dimensions: $66 \times 39 \times 15$ mm (Fig. 9.5).

The clearly biggest tool of the assemblage is a side-scraper made of local silex. Its left edge and the distal part of the right edge are retouched. Dimensions: 92×67×29 mm (Fig. 10.1). Some of such "gigantoliths" could be found in the excavated material from the Eger-Kőporos-tető site excavated by L.Vértes (Vértes 1951).

The last Szécsénke-Berecz-oldal site BO-4 consists actually of 3 little find concentrations on an area of $700 \mathrm{~m}$ length with only some pieces. The unity of these concentrations is obviously questionable, more than problematic, but for the sake of simpleness we discuss them together. The loess-like 


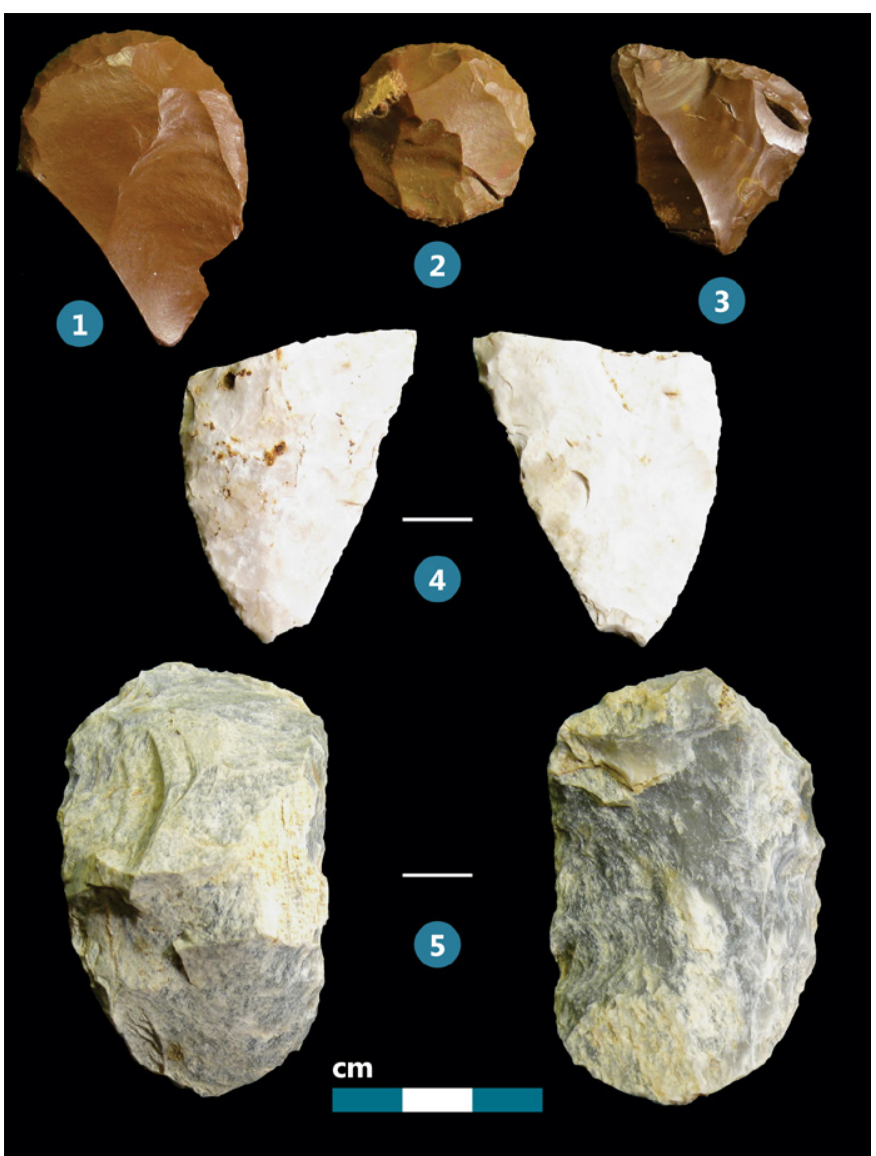

Figure 9. Selected tools from the Szécsénke Berecz-oldal BO-3 Palaeolithic site. 1: end-scraper made on flake, 2: circular end-scraper, 3: side-scraper of sub-triangular form, 4: asymmetric leaf-point, 5: sidescraper (1-3: Carpathian radiolarite, 4: limnic silicite of Cserhát Mts., 5: felsitic porphyry). //

9. ábra. Eszközök Szécsénke Berecz-oldal BO-3 paleolitikus lelőhelyről. 1: szilánkvakaró, 2: körvakaró, 3: szubtrianguláris kaparó, 4: aszimmetrikus levélhegy, 5: kaparó (1-3: kárpáti radiolarit, 4: cserháti limnoszilicit, 5: kvarcporfír).

soil cover at the foot of the Halyagos Mountain is relatively thick, perhaps due to understandable loess accumulation.

In the first concentration there are 7 pieces, 5 pieces of them are of local limnic silicite, 1-1 piece of silex and limnic silicite of Mátra Mountains origin. A quartzite notched tool of great dimensions $(54 \times 33 \times 21 \mathrm{~mm})$ with simple unretouched Clactonian notch is the only tool (Fig. 11.2). In the second concentration there are 6 artefacts, 4 of them are raw material chunks. There is a blade made of local limnic silicite and a flake core made of silex. In the third concentration among the 7 artefacts, there are 3 pieces made of local limnic silicite, 2-2 pieces of silex and radiolarite. There are 3 tools, an end-scraper and a worked piece made of limnic silicite. The third one is probably a base fragment of a leafpoint made of radiolarite. The longitudinal section could not be established, the cross section is slightly biconvex. The edges are worked with WGK. Dimensions: $(38) \times 31 \times 10$ mm (Fig. 11.1). Leaf-shaped tools made of Carpathian radiolarite are very scarce. The only known Palaeolithic industry with leaf-shaped tools which used radiolarite (of Transdanubian types) regularly is the Jankovichian industry postulated by Vera Gáboriné Csánk (Gábori Csánk. 1993). Dealing with leaf-shaped tools, Zs. Mester mentioned the published

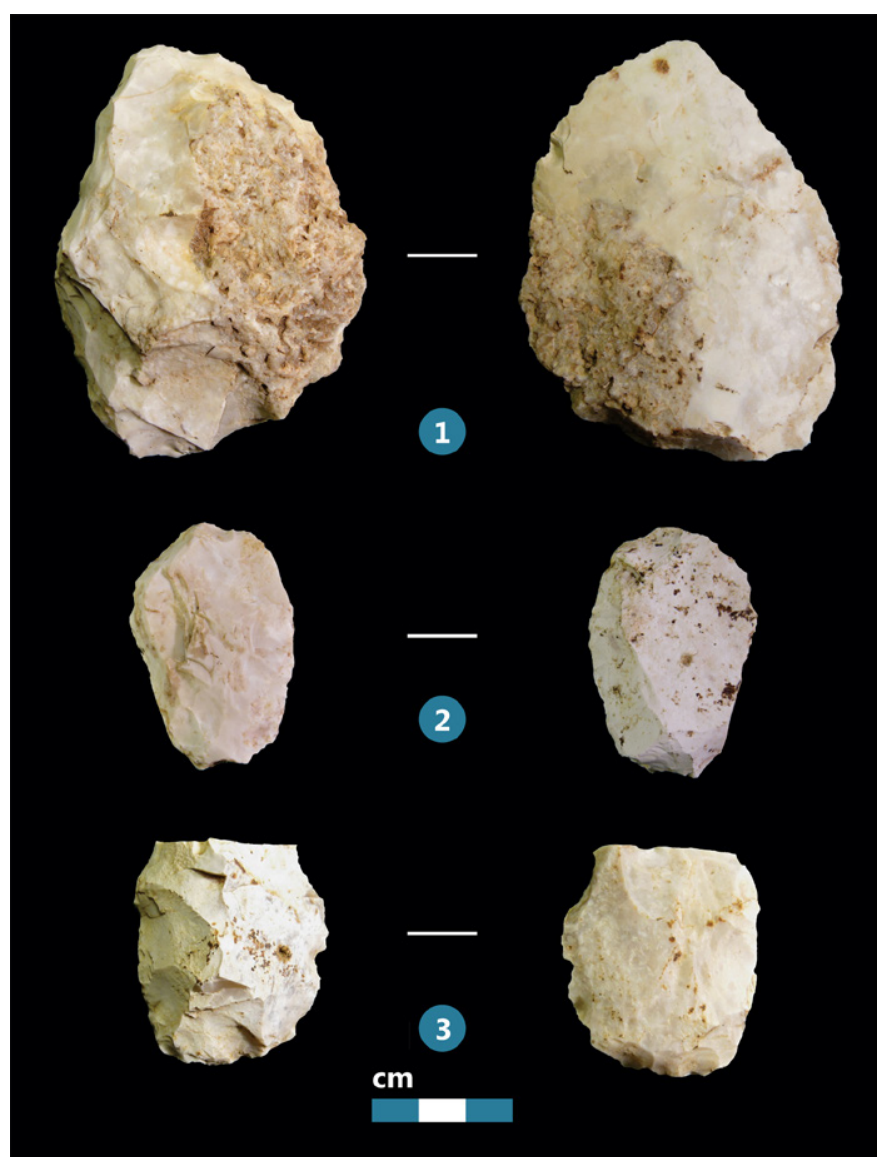

Figure 10. Selected tools from the Szécsénke Berecz-oldal BO-3 Palaeolithic site. 1: side-scraper of large dimensions, 2-3: bifacial tools (1-2: siliceous pebble, 3: limnic silicite of Cserhát Mts.). //

10. ábra. Eszközök Szécsénke Berecz-oldal BO-3 paleolitikus lelőhelyről. 1: nagy méretű kaparó, 2-3: bifaciális eszközök (1-2: kovakavics, 3: cserháti limnoszilicit).

examples of radiolarite artefacts that could be, on technotypological grounds, related to the Jankovichian industry (Mester 2008-2009: 82). The list of finds from the Cserhát Mountains contained two fragments with bifacial working made of Transdanubian (Szentgál-type) radiolarite at Galgagyörk-Májóka-3 (Markó et al. 2002: 255). This list could be extended now with an unpublished side-scraper fragment made of radiolarite from Buják-Rózsás-tető. This hill is the origin of a tabular, layered form of hydro- or limnic quartzite of better quality containing only few and small fossils (Markó 2005: 53-54).

\subsection{The Legénd-88 (LG-88) find concentration}

Fig 1.12 is a small find concentration. Stray finds were found here on a dirt road, at close quarters, actually next to the valley-sole. These finds are 4 leaf-points, 1 side-scraper with damaged working edge made on a silex pebble slice and a flake of felsititic porphyry. The loessy cover of the hilltop is thick, neither a larger archaeological site nor evidence of a smaller ephemeral hunting station could be localized. A seemingly reasonable situation would be the hypotetically assumption that the culture-bearing layer was somehow damaged by the forestry turnover on the dirt road. But in this curious case, four out of six stray finds are leaf-points, which is unusually high ratio. Actually we have 
absolutely no adequate geological explanation for this enigmatic phenomenon.

Basal fragment of a leaf-point made of local nummulitic chert. The tool has a narrow, elongated, symmetrical shape. Both the longitudinal and the cross section are biconvex. The edges are worked with WGK. On the whole, the shaping and the elaboration of this tool has rather a somewhat Micoquian-like character. Dimensions: 55×34×16 mm (Fig. 11.3).

Leaf-point made of local silex. The shape is approximately symmetrical to the longitudinal axis. Both longitudinal and cross sections are biconvex. The edges are worked with WGK. Dimensions: 62×36×13 mm (Fig. 12.1). In his paper dealing with the morphometrical analysis of the leaf-points of the Szeleta Cave, Zs. Mester defines 3 groups concerning of their length and width. Group 3 includes the smallest tools (length between 72 and $34 \mathrm{~mm}$, width between 40 and $24 \mathrm{~mm}$, and thickness between 12 and $8 \mathrm{~mm}$ ). This group is characterized by a low length/width ratio, and the greatest width is found between the middle of the length and the lower third of the tools. The most interesting result of the conducted analysis is the identical data set between Group 3 and the bifacial leaf-points of the Jankovich Cave. The above described leaf-point fits well in the Group 3 (3B-type because of the pointed base) of Szeletian bifacial foliate tools (Mester 2010: 111; 2011: 25).

This tool with its unusual short and broad form (length/ width ratio is 1,72) is a proper rarity in the Cserhát Mountains. There is only one vague morphological analogy at the relatively near site of Debercsény-Mogyorós attributed to the Szeletian industry (Markó 2009b: 157, Fig. 2.1). Further analogies can be found e.g. at Korlát-Ravaszlyuk (Simán 1999: 31, Table IV), at Jezeřany I (Oliva 1979: 62, Taf. III:4, IV:4), at Vedrovice V (Valoch 1993: 44, Abb.23: 4-5) and in the upper layer of Dzierźysław I. (Bluszcz et al. 1994: Fig. 6.2).

There are several pieces with similar morphological characteristics in the find horizon Ranis 2 of the Ilsenhöhle (Hülle 1977: 79, Taf. 21: 2, 52, Taf. 22: 2, 53, Taf. 23: 2, 55), in the Weinberghöhle caves at Mauern (Bohmers 1951: 55-56, Taf. 26: 2, 3; Zotz 1955: 97, Bild 46) or at Kösten (Zotz 1959: 51: 73, 52: 73-75). These sites are related to the Altmühlian (Altmühlgruppe) with blattspitzen of southern Germany.

Leaf-point made of C2E type grey-banded obsidian from the environs of Mád, Erdőbénye, Olasz-liszka. The shape is approximately symmetrical. Both the longitudinal and the cross section is biconvex. Dimensions: $46 \times(29) \times 7 \mathrm{~mm}$ (Fig. 12.2). Leaf-points made of obsidian are extremely rare.

- A broken piece is reported from the Szeleta Cave by Zs. Mester (Mester 2011: 37). Its cross section is biconvex. The edges are retouched with alternating retouching technique. Dimensions: $(58) \times(33) \times(10) \mathrm{mm}$ (Inv. $\mathrm{N}^{\circ}$ : 53.4.25)

- Another broken piece was mentioned by K. Simán (Simán 1985) at Sajószentpéter-Nagykorcsolás in Micoquian-Bábonyian context. Its both faces are thinned but only partially retouched. Dimensions: $22 \times 28 \times 9 \mathrm{~mm}$ (Inv. $\mathrm{N}^{\circ}:$ 82.8.55.).
- In Micoquian-Bábonyian context there is an interesting surface find from Galgagyörk-Csonkás-hegy made of Carpathian 2T obsidian (Markó 2004). It is a base fragment intentionally broken down from the tool. The edges are worked with WGK. The surface is covered by thick dehidration cortex. Dimensions: $(22) \times(24) \times(12) \mathrm{mm}$.

Basal fragment of a leaf-point made of local silex. The tool has a narrow, elongated, symmetrical shape. The longitudinal cross section is plano-convex, the cross section is biconvex. The edges are worked with WGK. Dimensions: $76 \times 33 \times 13$ $\mathrm{mm}$ (Fig. 12.3).

\subsection{The Kétbodony-Halyagos-hegy (HH) site}

In the bushy area on the top of the Halyagos-hegy with an altitude of of about $375 \mathrm{~m}$ a.s.l. no archeological site could be localized, but due to the erosion on a steep dirt road leading to the top of the hill stray finds could be found. The collected assemblage consists of 459 pieces. The raw material composition is very colourful. In the raw material utilization the local limnic silicite dominates (52.72 \%) but the ratio of the felsitic porphyry is very high too (30.94\%). Apart from these raw materials there are silex, quartzite, limnic silicite of Mátra Mountains origin, C1 and C2 type obsidian, erratic flint, jasper and unidentified raw materials. From felsitic porphyry as long distance raw material there are even tools. The great number of chunks, flakes and chips proves that intensive tool making and tool maintenance was practised on the site. Among the 13 tools, there are 2 end-scrapers, 1-1 leaf-point made of local limnic silicite and felsitic porphyry, 2 side-scrapers and 7 other worked pieces.

The shape of the leaf-point made of local limnic silicite is approximately symmetrical to the longitudinal axis. Both the longitudinal and the cross sections are plano-convex. The top-view is slightly deltoid. The edges are worked with WGK. Dimensions: $47 \times 24 \times 9$ mm (Fig. 13.1).

The leaf-point made of felsitic pophyry is abandoned due to the fracture properties of the raw material. The ventral face is a natural cleavage surface along a diaclase. Because of the cleavage properties of the raw material and due to a large hinge fracture the tool could not have been finished. The shape is approximately symmetrical to the longitudinal axis. Both the longitudinal and the cross section are planoconvex. Dimensions: 54×23×10 mm (Fig. 13.2).

A double side-scraper made of felsitic porphyry. The convex left edge is retouched rough-and-ready with semi-Quina retouch. The right edge is rather straight, it is bifacially retouched. The rough-and-ready notch seems to be intentional. Dimensions: $47 \times 24 \times 9 \mathrm{~mm}$ (Fig. 13.3).

There is an unusual combination of a double side-scraper and a splintered piece (pièce esquillée) made of Mátra limnic silicite. Dimensions: $37 \times 31 \times 8$ mm (Fig. 13.4).

The very heterogenous raw material composition and first of all the typological characteristics indicate that the assemblage consists the remains of probably more than one Palaeolithic industries. Among the other worked pieces there is a 
fragment of a backed bladelet characteristic for the Gravettian entity.

\subsection{Legénd-Rovnya (LGR) site}

\subsubsection{Geographical location}

The site is situated $3 \mathrm{~km}$ northwest of the village Legénd, on the northeastern fringe of the Romhányi Mountains, about $500 \mathrm{~m}$ from the $385.4 \mathrm{~m}$ high Rovnya Summit. The site is located on an approximately $250 \times 100$ meter relatively flat plateau. The relative height from the sole of the Halyagos Streamlet is about $60-70 \mathrm{~m}$. South of the site one can find some "dead end valleys". The most important of them is the source of the Sápi Streamlet. Due to afforestation the site can not be collected anymore. The assemblage of the site was recently published in Hungarian language with a short English résumé (Péntek-Zandler 2013b) and there is an unpublished paper in English (Péntek 2015a).

\subsubsection{Raw materials of the archaeological assemblage}

The chipped stone assemblage contains 972 pieces. The most dominant raw material is local limnic silicite with 756 pieces (77.78 \%). Two raw material assortments, silex and quartzite, should be regarded as local. The ratio of the silex with 166 pieces is $17.08 \%$ in the total assemblage but it is significantly higher among the tools with 22 pieces, namely $47.83 \%$. The ratio of the 19 pieces quartzite in the total assemblage is $1.95 \%$. All other raw materials have an anecdotical role. The two long distance raw materials, felsitic porphyry and Carpathian 1 type obsidian are represented by $5-5$ pieces $(0.51 \%)$. There are 13 pieces of Carpathian radiolarite (1.34 \%) and 6 pieces of erratic flint (0.62 \%).

\subsubsection{Technology and typology}

The Palaeolithic industry is a typical flake-industry, the laminarity is very low, there are only 2 Aurignacian-like retouched blades and two Gravettian-like backed bladelets. There are no signs of Levallois-debitage, the application of the bifacial technique can be observed only at the leafshaped tools.

In the assemblage collected from the surface there are 54 formal tools mostly made of limnic quarzite. The Palaeolithic and younger prehistoric stone tools were separated on strict techno-typological basis. We classified 46 tools belonging to the Palaeolithic industry. Among the Palaeolithic formal tools we distinguished 4 fundamental tool categories. The given percentages have only informative value since the number of the tools is less than 100 .

There are altogether 16 pieces of flake end-scrapers (34.78 $\%)$. The blanks have generally a massive, slightly elongated, blade-like form. There is a raw material preference, 4 pieces were made of limnic quartzite, 1 piece of radiolarite and the rest of silex. Morphologically the end-scrapers are very variable, most of the pieces have a convex working edge. The Upper Palaeolithic end-scraper types are represented by 6 rather atypical pieces, there are 5 pieces of carinated end-scrapers and one nosed end-scraper. However, on the whole, typologically end-scrapers make an Aurignacian-like impression. On Fig. 16.7 a carinated end-scraper made of siliceous pebble can be seen. One small sized subcircular end-scraper resembles the so called groszak (Typ Heidenschmiede, Bosinski 1967: 33) of the Micoquian industries. The lateral retouching is not so frequent, but it is a common phenomenon at the Moravian Szeletian sites e.g. at the recently excavated Želešice III (Škrdla et al. 2014: 92, Fig. 12:13, 98, Fig. 12: 13, 15, 16).

Ventral thinning of the proximal part and elimination of the bulb occur sometimes. These phenomena are well known at the Moravian or Bavarian Szeletian sites like Trboušany (Hladíková 2002: 78, Obr. 9: 3, 4, 7) and Zeitlarn (Schönweiss-Werner 1986: 10, Abb. 3: 8; Heinen-Beck 1997: 84, Abb. 7: 5, 6.) as well as in the Cserhát Mountains, for example at Galgagyörk-Csonkás-hegy (Markó et al. 2002: 249, Fig 2.1, 2.4) and Legénd-Káldy-tanya (Markó-Péntek 20032004: 169, Fig. 4.7).

On one occasion the direction of the detachment could not be determined unambiguously, that is why this piece can be classified perhaps rather as side-scraper. It has a very characteristic attribute typical for the Polish or German Micoquian industries (Keilmessergruppe), namely the so-called Prądnik-technique. It is present at some archaic Szeletian sites in Moravia as Jezeřany I. and II. (Oliva 1979: 48). We have another example in the Cserhát Mountains, the above mentioned bifacial knife from the KFH site.

The tool category of the leaf-shaped tools consists of 5 pieces $(10.87 \%)$. Three pieces were made of silex, 1-1 piece of limnic quartzite and of felsitic porphyry. Altogether 3 pieces could be interpreted as leaf-points. A common characteristic is the WGK. The 2 small sized leaf-points should be correlated to the nearby Szeletian site at KFH site, a greater but broken piece resembles the Micoquian-Bábonyien pieces of the Legénd-Káldy-tanya (Markó-Péntek 2003-2004: 168, Fig.3).

On Fig. 14.1 a leaf-point made of felsitic porphyry can be seen. The shape is symmetrical. Both the longitudinal section and the cross section are plano-convex. The top-view is slightly rhomboid (trapezoid). The edges are worked with WGK. Dimensions: $49 \times 22 \times 8 \mathrm{~mm}$. Another leaf-point made of local silex, has a near biconvex longitudinal and cross section. The piece has an unusual asymmetrical shape, the left edge is curved, the right edge is rather angular. The edges are worked with WGK. Dimensions: $47 \times 27 \times 9 \mathrm{~mm}$ (Fig. 14.2, Fig. 16.1). A leaf-point made of local silex, has a near biconvex longitudinal and cross section. The piece has a narrow, symmetrical, elongated form, which is present even in the Micoquian-Bábonyian industry (Zandler-Béres 2014: 76, Fig. 5). The edges are worked with WGK. Dimensions: $(44) \times 24 \times 10$ mm (Fig. 14.3, Fig. 16.3).

There are 6 pieces (13.04\%) in the category of the sidescrapers. Two double side-scrapers were made of felsitic porphyry, one of them can be seen on Fig. 16.2. From the 




Figure 11. Selected tools from the Szécsénke Berecz-oldal BO-4 (12) and Legénd-\#88 (3-4) Palaeolithic sites. 1: base fragment of a leafpoint, 2: notched tool, 3: side-scraper, the working edge is damaged; 4 : basal fragment of a leaf-point (1: Carpathian radiolarite, 2: quartzite, 3 : siliceous pebble slice, 4: nummulitic chert). //

11. ábra. Eszközök Szécsénke Berecz-oldal BO-4 (1-2) és Legénd-\#88 (3-4) paleolitikus lelőhelyekről. 1: levélhegy bázistöredéke, 2: völgyelt eszköz, 3: roncsolt munkaélű kaparó; 4: levélhegy bázistöredéke (1: kárpáti radiolarit, 2: kvarcit, 3: kovakavics gerezd, 4: nummuliteszes kova).

2 simple side-scrapers with straight working edge, 1 piece was made of nummulitic chert, 1 piece of radiolarite. Two large pieces were made of quartzite. The one piece is a sidescraper or roughly elaborated denticulated tool on a massive déjeté flake. Only the approximately straight distal part of the right edge is grossly retouched, actually denticulated. Dimensions: $64 \times 46 \times 22 \mathrm{~mm}$. The ventral face shows a typical pronounced bulb of percussion (Fig. 15.1). The other quartzite side-scraper is a natural backed tool (racloir à dos naturel) on a massive déjeté flake. The left edge forms the back, the right edge is rough-and-ready, but bifacially elaborated. Dimensions: 66×44×19 mm (Fig. 15.2).

The last tool category of other tools or worked pieces contains 19 pieces altogether (41.30\%). Of these tools only few pieces could be identified precisely, the most pieces are namely broken. It is worthy to emphasize the presence of two Aurignacian-like retouched blades (Fig. 16.4-5). One of the latter has an oblique distal end with two notches. The two backed bladelets seem to belong to the Upper Palaeolithic Gravettian culture. These finds should maybe correlated to the Gravettian site at Romhány-Diós (Simán 1993; Dobosi 2011), which lies about 8-10 km west from our site.

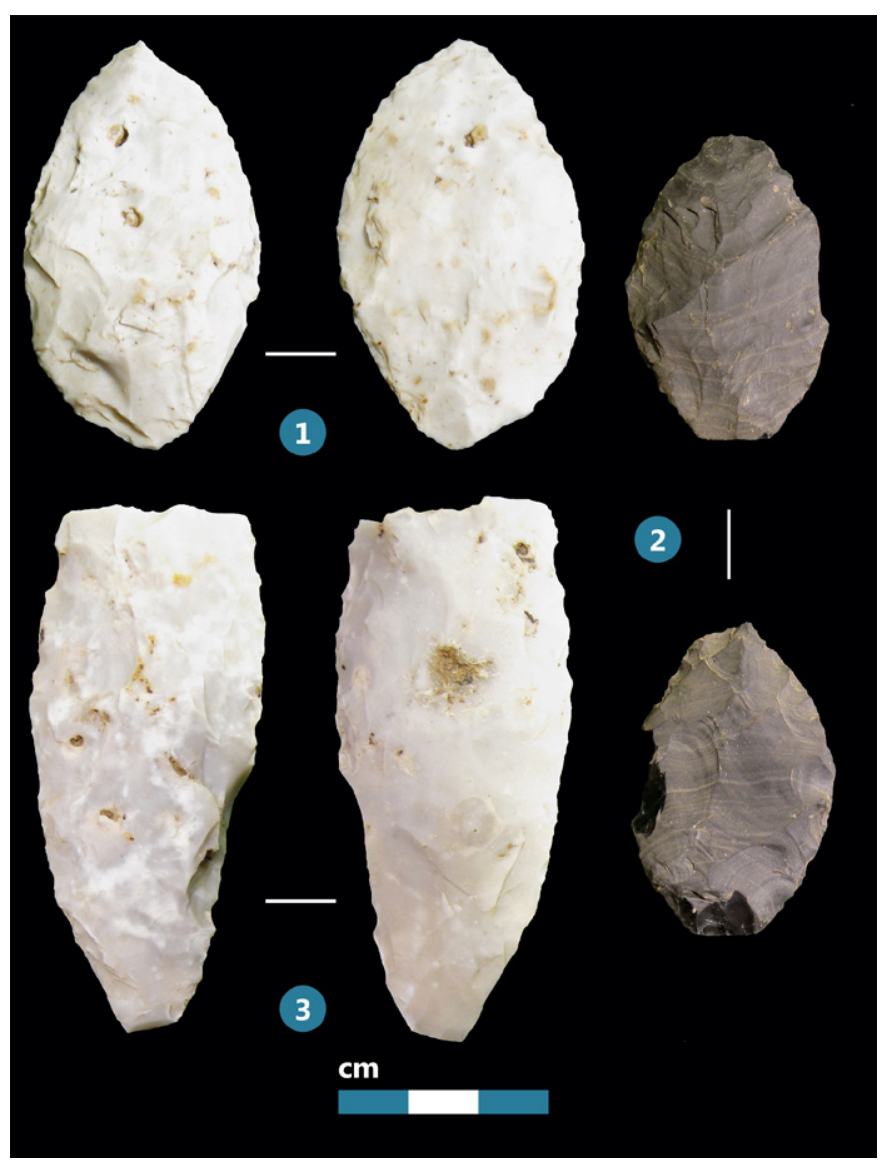

Figure 12. Selected tools from the Legénd-\#88 Palaeolithic site. 1-3: leaf-points (1,3: siliceous pebble, 2: Carpathian C2E type grey-banded obsidian). //

12. ábra. Eszközök Legénd-\#88 paleolitikus lelőhelyről. 1-3: levélhegyek (1,3: kovakavics, 2: kárpáti C2E típusú szürke sávos obszidián).

Unfortunately until now there are very scarce traces of the Upper Palaeolithic in the Middle and Western Cserhát Mountains. Most of the Gravettian sites can be found in the valley of the Galga River, for example at Püspökhatvan (Cs. Balogh-Dobosi 1995) and Csővár-Arany-hegy with unpublished archaeological material. The site at ErdőtarcsaDaróci-hegy (Zandler 2008) yielded a typologically mixed material. The Upper Palaeolithic types seem to belonging rather to the Aurignacian. In the direct environs of Legénd village recently some small find concentrations have been found (Legénd-Hosszú-földek, Legénd-Remete) with very strong Upper Palaeolithic affiliation.

\subsubsection{Discussion of the LGR site}

The artefacts collected from the surface are not suitable for a more minute cultural classification, which is mainly due to the relatively few number of tools. We regard the Palaeolithic material of the site as inhomogeneous. A possible explanation for this fact could be the optimal topographical situation for hunting. Therefore the area was very attractive during prehistoric times. On the opposite side of the valley of the Halyagos Streamlet, on the Halyagos-hegy, about $750 \mathrm{~m}$ from the LGR site at an altitude of cca. $375 \mathrm{~m}$ a.s.l. there is the above mentioned $\mathrm{HH}$ site with unpublished material. It seems to be evident that these two sites had the same or very similar strategic importance as 


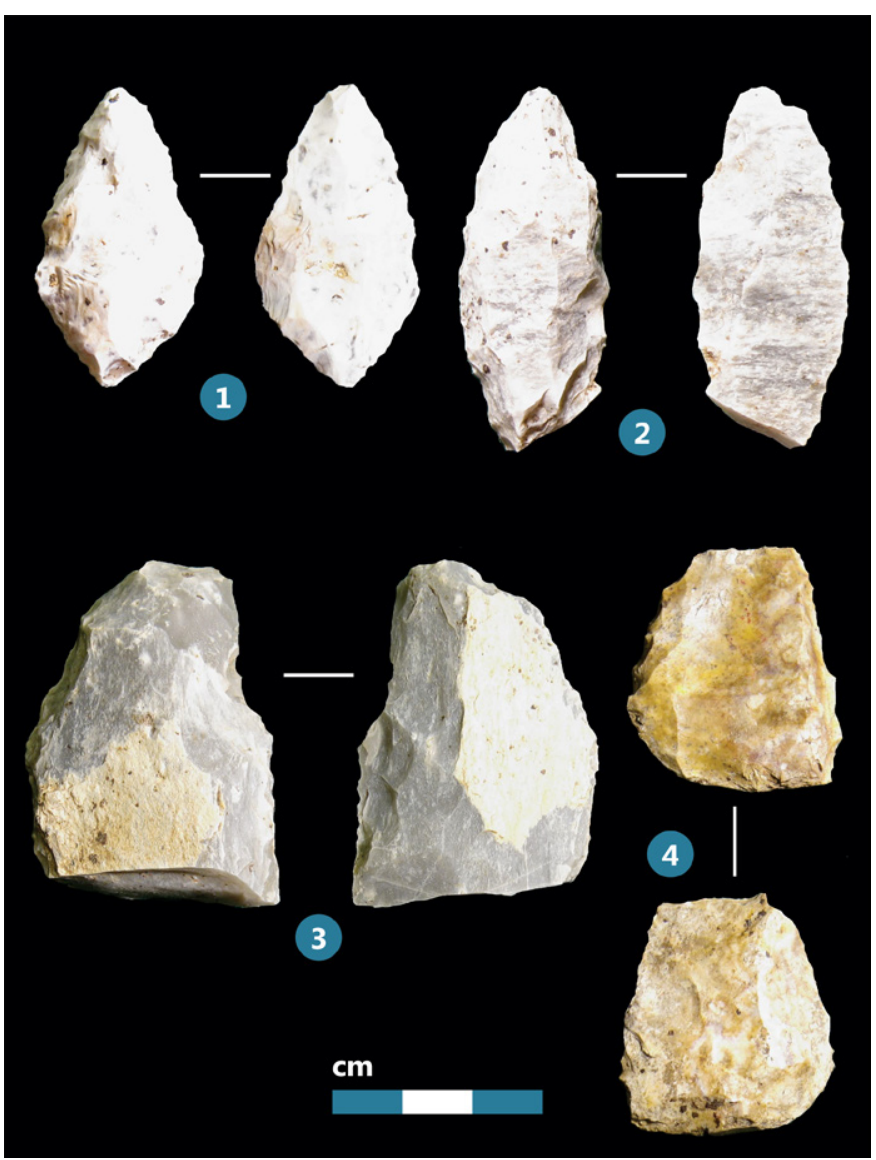

Figure 13. Selected tools from the Kétbodony-Halyagos-hegy $(\mathrm{HH})$ Palaeolithic site. 1: leaf-point, 2: leaf-point, it is abandoned due to the fracture properties of the raw material, 3: double side-scraper, 4: splintered piece (pièce esquillée) (1: limnic silicite of Cserhát Mts., 2-3: felsitic pophyry, 4: limnic silicite of Mátra Mts.). //

13. ábra. Eszközök Kétbodony-Halyagos-hegy $(\mathrm{HH})$ paleolitikus lelőhelyről. 1: levélhegy, 2: levélhegy, melyet az anyagban lévő repedés miatt félbehagytak, 3: kettős kaparó, 4: pikkelyretusú darab (pièce esquillée)

(1: cserháti limnoszilicit, 2-3: kvarcporfír, 4: mátrai limnoszilicit).

hunting stations ("high-stands" or "watchposts") in controlling the movement of game animals in the valley.

Among the Palaeolithic tools there are both tools which are characteristic for the Micoquian-Bábonyian and that ones which are characteristic for the Szeletian industry and there are some more or less typical Upper Palaeolithic (Aurignacian and/or Gravettian) types too.

\section{Conclusion}

\subsection{Raw material utilization of the affected sites}

The main characteristics can be summarized as follows (Table 1, Table 2):

- The most dominant raw material is the local limnic silicite, probably from Galgagyörk and Püspökhatvan (Cs. Balogh-Dobosi 1995).

- Utilization of other local raw materials in the region such as silex and quartzite is as intensive as at the KFH site. The ratio of the used silex is extraordinary high on the BO-2E ( $32.3 \%$ of the total).

- In contrast to the KFH site the occurence of the limnic

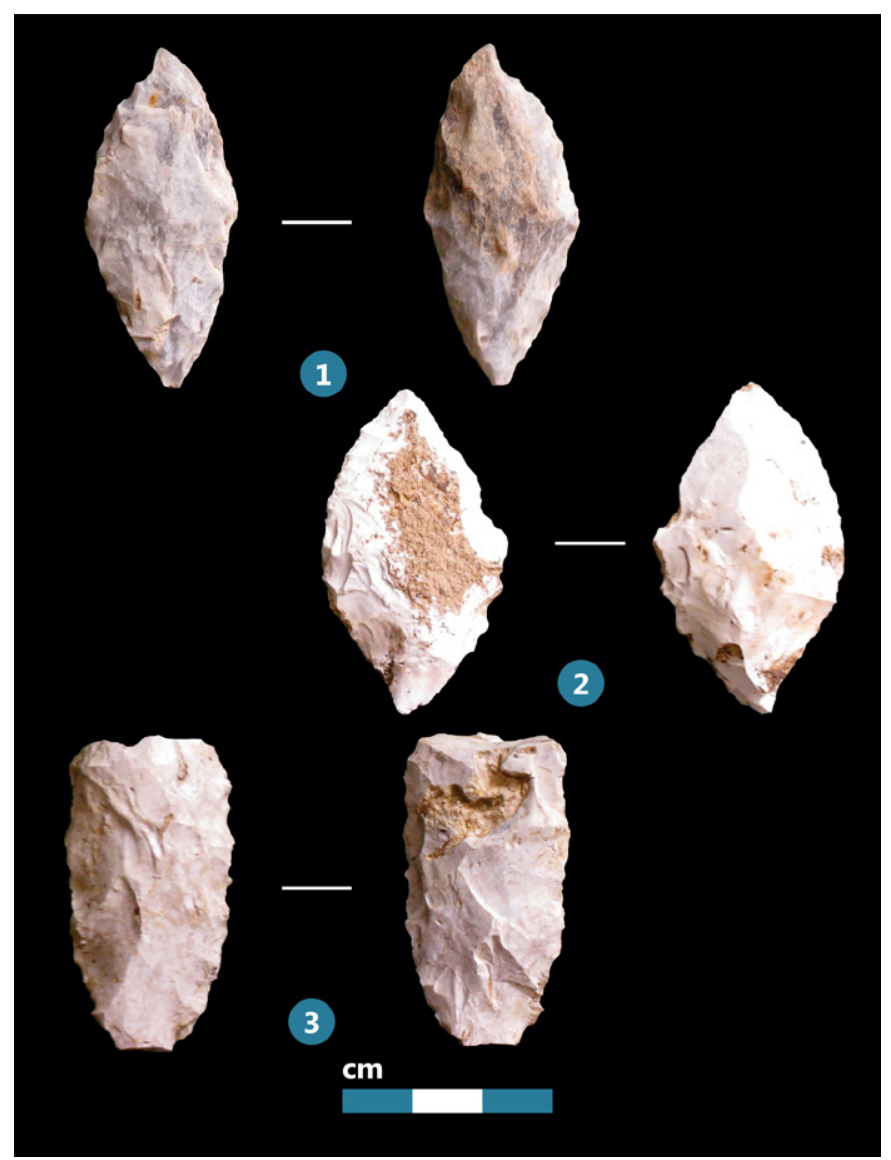

Figure 14. Selected tools from the Legénd-Rovnya (LGR) Palaeolithic site. 1-3: leaf-points (1: felsitic pophyry, 2: limnic silicite of Cserhát Mts., 3: siliceous pebble). //

14. ábra. Eszközök Legénd-Rovnya (LGR) paleolitikus lelőhelyről. 1-3: levélhegyek (1: kvarcporfír, 2: cserháti limnoszilicit, 3: kovakavics).

silicite of the Mátra Mountains can be observed as well. It is markedly high on the BO-2W (16.54\%). Strikingly few debris of those limnic silicite could be found, because of the distance to the raw material sources, most artefacts were imported either as finished tools or as blanks for tool production.

- There are some exotic regional materials such as jasper, lydite of uncertain origin. They are probably from the Mátra Mountains but in small amounts they can be found even in some gravel beds in the Cserhát Mountains.

- All pieces of the Carpathian radiolarite of uncertain provenance belong to the dark brown colour variant but without the greenish marbly pattern characteristic of the White Carpathians (Vlára Valley). This raw material is represented mostly by tools, no or very few debitage can be found. The ratio of the tools made of radiolarite is in general somewhat higher as at the KFH site.

- In contrast to $\mathrm{KFH}$,the role of the long distance felsitic porphyry raw material seems to be subordinated at the other sites, there are mainly tools made of it. The only exception with a ratio of $30.94 \%$ is the HH (Halyagoshegy) site, where besides tools, considerable amount of chunks and debitage, even small retouching chips can be found, proving local tool making and resharpening. In connection with the side-scrapers of small dimensions made of felsitic porphyry at the KFH site it was above expected that there was a saving housekeeping practised. That is namely the important factor, which should be stressed, the need to "maximize the number of flakes 
(or edges) per core at the expense of flake size" in oder to save raw material (Kuhn 1995: 33).

- Other long distance raw materials such as Northern erratic flint are represented only sporadically with a few pieces.

\subsection{Techno-typological remarks}

The main characteristics can be summarized hereinafter.

- All sites show a flake-industry character but in contrast to the KFH site a little bit higher laminarity can be observed elsewhere, and there are some blade cores (abandoned and exhausted) too. However, the ratio of blades is nowhere higher than $3.11 \%$ (at BO-2E site).

- Among the tools the end-scrapers are the most frequent. They have various morphology but the evidently Upper Palaeolithic types are lacking. There is generally a definitive raw material preference, the mostly pieces are made of local limnic silicite and silex.

- The lateral retouching of the end-scrapers has a very frequent occurrence, but the ventral thinning and the elimination of the bulb is relatively rare compared to the KFH site.

- There are relatively less side-scrapers, the most pieces are made of felsitic porphyry and silex, but there are even rough-and-ready made pieces made of quartzite on the LGR site.

- The shape and the dimensions of the leaf-points are various. There are both wide and narrow leaf form with tipped base, and there are some pieces with rounded base again. There are narrow, elongated points which occur both in the Micoquian-Bábonyian as well in the Szeletian industry. The pieces with slightly deltoid or rhomboid top-view are present too.

- The longitudinal section is generally biconvex. The most pieces have plano-convex or biconvex cross sections. A common technological characteristic is the so-called WGK (wechselseitig gleichgerichtete Kantenbearbeitung) which is a typical attribute of the Micoquian-Bábonyien industry and is not an alien phenomenon in the Early Szeletian industry.

- In contrast to the KFH site apart from the the leafpoints, other types of bifacial tools occur only sporadically or even fail.

We regarded the Kis-Ferenc-hegy site at Szécsénke as a relatively early, open-air Szeletian site.

If we consider the differences between the KFH site and the sites in the discussed site complex as the signs of some kind of development, we should attribute these sites culturally related to the KFH site but possibly belonging to a younger or developed phase of the Szeletian or of a Szeletian-like industry with leaf-points. A detailed techno-typological comparison with the collection from the Hont-Csitár site, as benchmark, would be more than desired.

\subsection{Some thoughts about settlement dynamics and landscape use pattern}

According to the recent cognitions, based only on the intense surface collections, it would be a very hazardous trial to present an interpretation on the above reviewed sites and on their relationship.

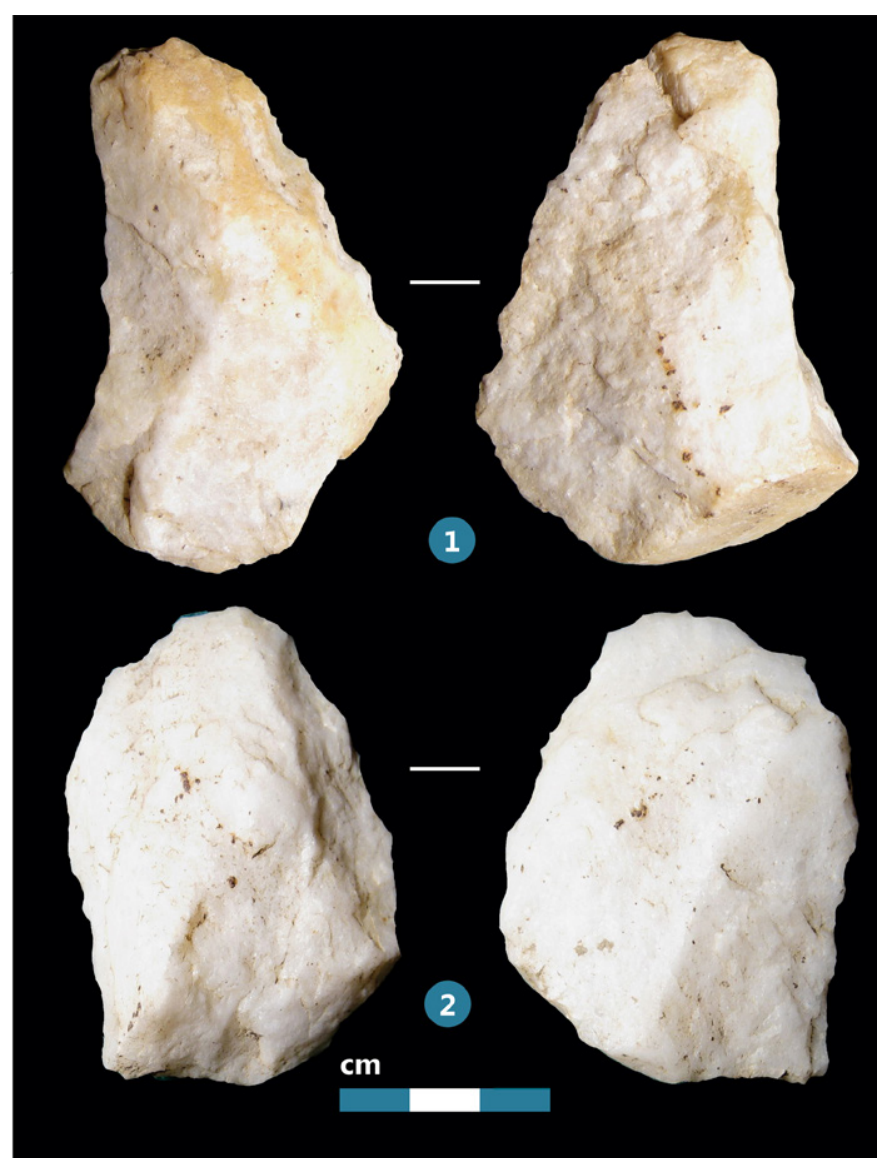

Figure 15. Selected quartzite tools from the Legénd-Rovnya (LGR) Palaeolithic site. 1: side-scraper or roughly elaborated denticulated tool; 2: side-scraper with a natural back (racloir à dos naturel). //

15. ábra. Eszközök Legénd-Rovnya (LGR) paleolitikus lelőhelyről. 1: kaparó, vagy durván kiképzett fogazott eszköz; 2: természetes hátú kaparó (racloir à dos naturel).

As M. Bolus stated in his paper (Bolus 2004: 204) the spectrum of the variables providing at least limited informations concerning the settlement system is wide. It includes not only the regional distribution of sites, the landscape use, raw material procurement, but the spatial organization and functional differentation of the sites as well.

Several Middle Palaeolithic settlement types concerning the intensity and duration of occupations and the number of activities carried out on the site, are known from the Crimea (Marks-Chabai 2001: 191-195; Chabai-Uthmeier 2006; Bataille 2010; 2012). Ephemeral sites (both kill-butchering loci and camps) have a significant trait in the raw material procurement, namely the utilization of mostly imported resources. That is, the occurence of local (originating less than $5 \mathrm{~km}$ from the site) raw material assortments is very rare and there are only scattered data about on-site core reduction or tool making. The tool composition is narrow and related mainly to the „kill-butchery” activity. These occupations, mainly the kill-butchering loci, represent one of the most ephemeral, limited-activity site types which is archaeologically visible (Marks-Chabai 2001: 191). However, very striking is the investigation on the two horizons of the deeply stratified Middle Palaeolithic site Kabazi II, belonging to the Crimean Micoquian (Bataille 2012). 

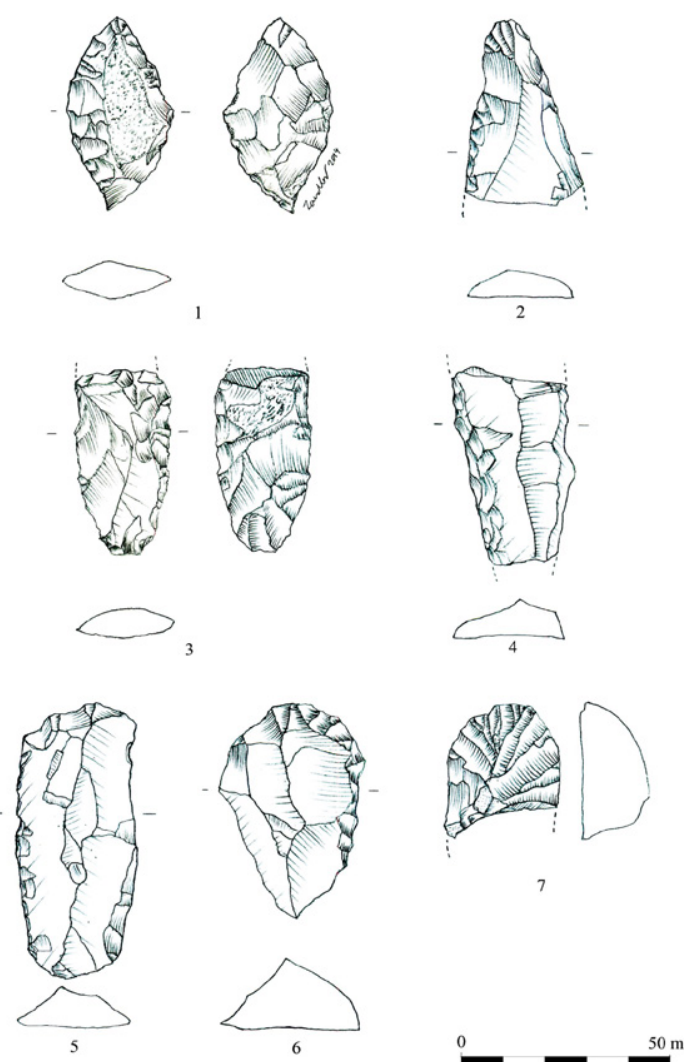

7

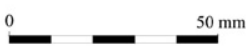

Figure 16. Selected tools from the Legénd-Rovnya (LGR) Palaeolithic site. 1, 3: leaf-points, 2: double side-scraper, 4: retouched blade, 5: retouched, truncated blade, 6: end-scraper made on flake, 7 : carinated end-scraper (1, 4-6: limnic silicite of Cserhát Mts., 2: felsitic porphyry, 3,7: siliceous pebble) [drawn by K. Zandler]. //

16. ábra. Eszközök Legénd-Rovnya (LGR) paleolitikus lelőhelyről. 1, 3: levélhegyek, 2: kettős kaparó, 4: retusált penge, 5:retusált és csonkított penge, 6: szilánkvakaró, 7: orros vakaró (1, 4-6: cserháti limnoszilicit, 2: kvarcporfír, 3,7: kovakavics) [rajz: Zandler K.].

To sum up, "It is obvious that the investigated Micoquian levels exhibit an ephemeral character. Levels III/2 and III/1 represent butchering stations of very short duration. Only few stone artifacts belong to single occupations. The main activities focus on the provisioning of camp sites with game while the lithic material can be interpreted as by-products for meat processing." (Bataille 2012: 204).

In short-term camps the blanks and tools arriving at the site from some distance occur with the local raw material together. Lithic raw material economy varies according to distance from a raw material source. On the surface activity or functionality zones or specific tool distribution patterns or densities could be observed. These camps seem to reflect a somewhat larger range of activities and, perhaps, a somewhat greater duration of occupation. The tool spectrum according to the activities could be also somewhat broader.

In the considerably amount of literature dealing with settlement dynamics, settlemens structure etc. there are some quasi synonym denominations for the term „base camp”, which was occupied for a considerable period, e.g. for a

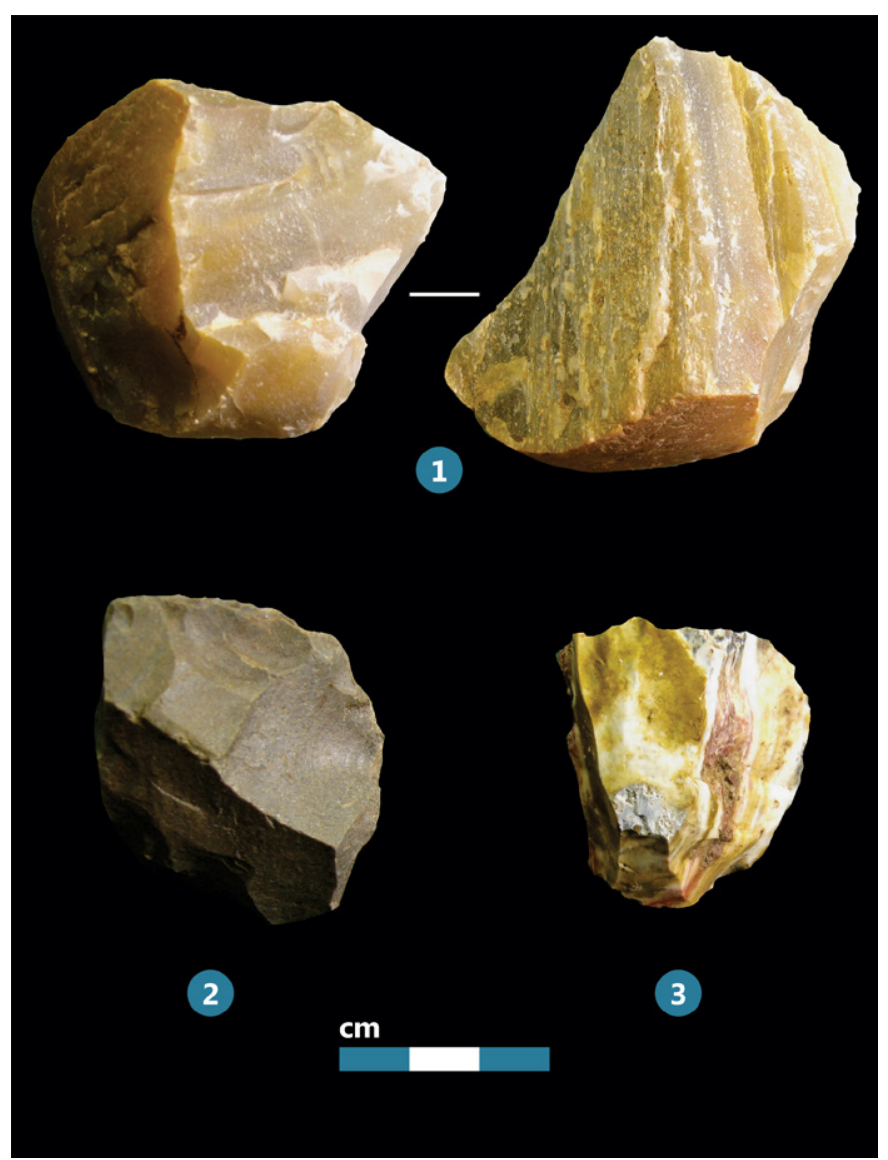

Figure 17. 1: flake core from the $\mathrm{BO}-1$ site; $2-3$ : selected flake cores from the $\mathrm{BO}-2 \mathrm{E}$ site (1: quartzite, 2: orthoquartzite, 3: limnic silicite of Mátra Mts.). //

17. ábra. 1: szilánkmagkő a BO-1 lelőhelyről; 2-3: szilánkmagkő példák a BO-2E lelőhelyről (1: kvarcit, 2: ortokvarcit, 3: mátrai limnoszilicit).

number of months. A. Verpoorte (Verpoorte 2006, after Kelly) uses the term "central place", at T. Hopkinson we find its equivalent as "center of social action" (Hopkinson 2006: 229). In the assemblages of the „base camps” the tool making from the local raw material seem to be extended with the processing of long distance raw materials. Because of the greater permanency of residence, a larger number of activities took place over time, resulting in greater number and variability of artefacts, the tool composition is much more rich and various.

Another classification was proposed especially in connection with the sites of the Blattspitzen complex in Central Europe by M. Bolus (Bolus 2004). In his paper he summarizes the archaeological evidence for this technocomplex with regard to the spatial organization and functional interpretation of the sites and on that base he identifies three site types. The first type includes large open-air sites, which are often situated near raw material sources. In most cases these sites are known for extensive surface scatters, sometimes with several smaller find concentrations, which are separated from each other by gaps, areas without lithic finds. This type of sites, like Vedrovice V in Moravia (Czech republic) or Zeitlarn in Bavaria was repeatedly visited over a long period of time and should be interpreted as palimpsests. An important argument in summing up the features of these sites that the raw material of the artefacts indicates 
a well-aimed exploitation of the nearby raw material sources, the leaf-points seem to have been made on the spot. An another aspect is the high amount of debris at the site which should reflect the remains of knapping activities from several settlement occupation events.

The second type of sites is defined as cave sites with relatively few archaeological material, containing at times more than one Blattspitzen horizons. The density of finds is higher but still relatively low compared to the rich open-air sites of the first group. These sites have a less clear or uncertain function, the small number of artefacts and the sometimes limited toolkit do not indicate long-term stays. It is more plausible that these sites were repeatedly used for shortterm stays, most probably related to hunting activities. In general there is no evidence for leaf-point production.

The third group composed both of open-air and cave sites. These are characterized with small or very small Blattspitzen assemblages. It is always questionable to put a single stray find of a leaf-point into this category without further investigations of the find spot. The majority of the sites of this third group could be interpereted as remains of shortterm hunting stays.

We must proceed by the process of elimination to try to fit in the sites at Szécsénke in some classification scheme. The little scattered find concentrations like BO-4 an LG-88 should be interpreted most probably as ephemeral sites, perhaps hunting stations sensu Marks and Chabai (2001) or belonging to the third group sensu Bolus (2004).

Concerning the raw material composition, exclusive of the above mentioned sites, there are seemingly four different distribution schemas:

- KFH site: a relatively balanced distribution between the local raw materials, limnic silicite and siliceous pebbles and the long distance raw material, felsitic porphyry, 42-17-38\% respectively.

- HH site: a relatively balanced distribution between the local raw materials, limnic silicite and siliceous pebbles and the long distance raw material, felsitic porphyry, 54-6-31 \% respectively. Unpronounced presence of other regional and long distance raw materials.

- BO-1, BO-3, LGR: absolute dominance of the local raw materials, mostly limnic silicite. Unpronounced presence of other regional and long distance raw materials.

- BO-2E, BO-2W: absolute dominance of the local raw materials, the ratio between limnic silicite and siliceous pebbles is more balanced. Unpronounced presence of other regional and long distance raw materials.

Based on the aforementioned assemblages, no sites should be either interpreted as ephemeral sites or as base camp sensu Marks and Chabai (2001). They should belong to the provisional camps but alone the surface collection would never prove the existence of surface activity or functionality zones. It was mentioned above that the BO- 1 site is possibly composed from two smaller find concentrations. The site can be regarded most probably as the remains of two short-term stays and should be put in the third group sensu Bolus (2004).

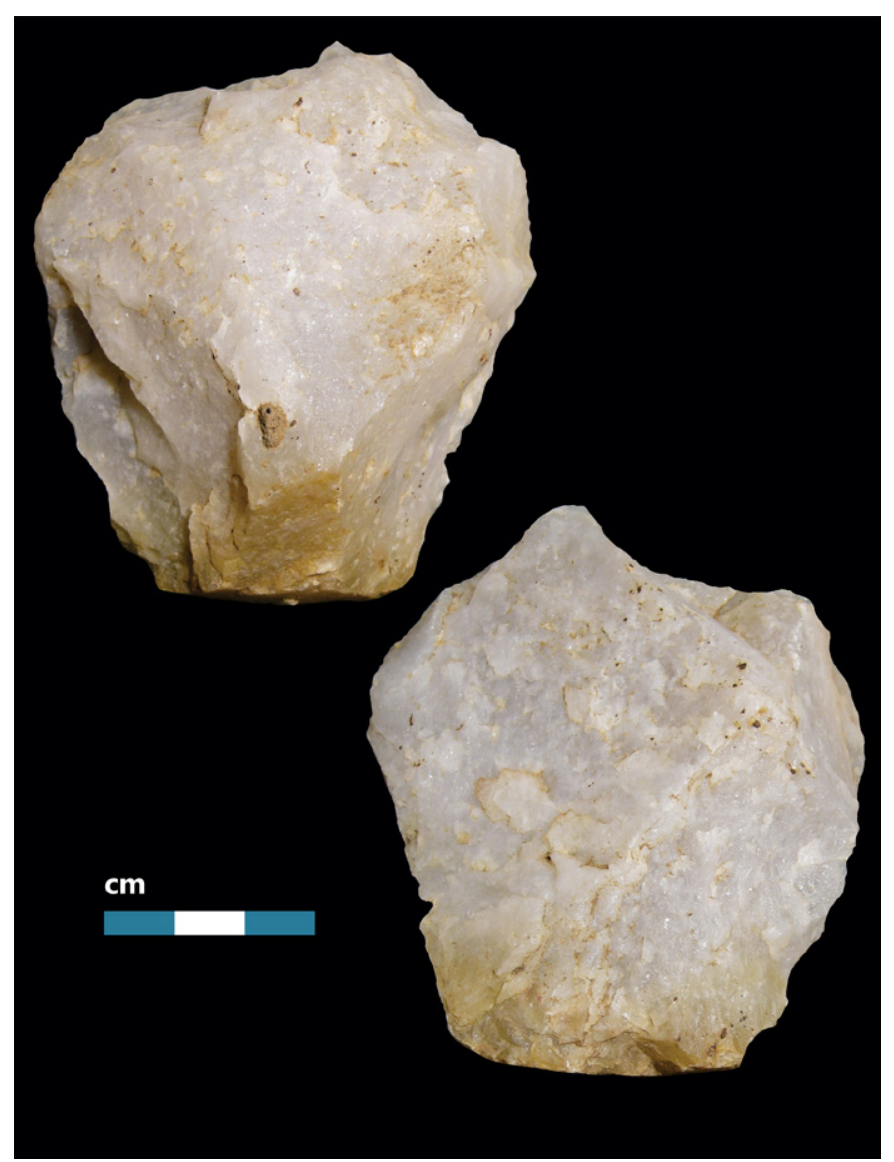

Figure 18. Quartzite flake core from the BO-3 Palaeolithic site. // 18. ábra. Kvarcit szilánkmagkő a BO-3 paleolitikus lelőhelyről.

During the surface collection not even on the richest site, KFH could be separate find or tool concentrations observed. There is no indication for specific activity or functionality zones, hence it does not fulfill the defining criteria for a site being base camp. On the contrary, the artefact distribution is rather balanced overall. It seems to be very life-like to imagine a short-term stay of a prehistoric group of 5-8 families, maybe 30-40 people on an area of 150-250×100-200 m in order to hunting and stocking their supply. This statement should be valid actually for all the sites $\mathrm{KFH}, \mathrm{BO}-1$, BO-2E, BO-2W, BO-3, HH, LGR, and so they can be regarded as belonging to the first group sensu Bolus (2004). However these sites can be interpreted likely as palimpsests of several short-term stays.

Hopefully, due to further surface collection activities, the intrasite relations could be cleared in some degree too. So, for example the connection or relation between the BO-2E and $\mathrm{BO}-2 \mathrm{~W}$ sites is not clear. It is thinkable that as a matter of fact, there is only one site. An other question to be answered is the function of the $\mathrm{HH}$ site and its relation to the opposing site LGR, lying on the southern side of the Halyagos Streamlet. Aside from the felsitic porphyry, the two sites have a more or less similar raw material composition. On techno-typological grounds both site seem to yielded a mixed material. Most probably we should regard the assemblage of the $\mathrm{HH}$ site partly, taking notice of the high amount of felsitic porphyry, being in connection or relation with the KFH site. 


\begin{tabular}{|c|c|c|c|c|c|c|c|c|c|c|c|c|c|c|c|c|c|}
\hline \multicolumn{2}{|l|}{$\begin{array}{l}\text { Szécsénke site } \\
\text { complex }\end{array}$} & $\begin{array}{l}\text { RM1 } \\
\text { Lo- } \\
\text { cal LS }\end{array}$ & \multicolumn{5}{|c|}{ RM2 Local } & \multicolumn{3}{|c|}{ RM3 Mesolocal } & RM4 & \multicolumn{2}{|c|}{$\begin{array}{c}\text { RM5 } \\
\text { Extralocal }\end{array}$} & $\begin{array}{l}\text { RM6 } \\
\text { Extra- } \\
\text { local }\end{array}$ & RM7 & RM8 & \\
\hline $\begin{array}{l}\text { Lithic artefacts } \\
\text { / Raw material }\end{array}$ & & 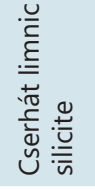 & $\begin{array}{l}\frac{0}{\frac{1}{n}} \\
\frac{d}{0} \\
\frac{c}{4}\end{array}$ & 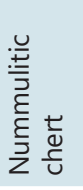 & $\frac{\frac{N}{0}}{\frac{N}{0}}$ & $\begin{array}{l}\frac{0}{N} \\
\frac{N}{0} \\
\frac{0}{0}\end{array}$ & 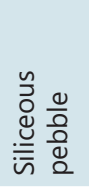 & $\begin{array}{l}\frac{\bar{\nu}}{0} \\
\frac{0}{0} \\
\text { I্ }\end{array}$ & $\stackrel{0}{\frac{0}{0}}$ & 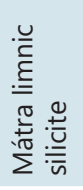 & 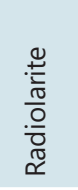 & $\begin{array}{l}\bar{U} \\
\bar{c} \\
. \frac{\pi}{0} \\
\overline{\frac{0}{n}} \\
\tilde{O} \\
0\end{array}$ & $\begin{array}{l}\tilde{U} \\
\frac{\pi}{\pi} \\
\frac{\pi}{0} \\
\frac{0}{n} \\
0 \\
0\end{array}$ & 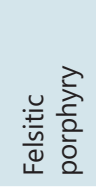 & 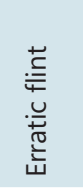 & 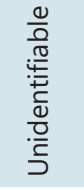 & $\begin{array}{l}\frac{0}{a} \\
\frac{1}{\sqrt{0}} \\
\frac{0}{0}\end{array}$ \\
\hline \multirow[t]{2}{*}{$\begin{array}{l}\text { Szécsénke-Kis- } \\
\text { Ferenc-hegy }\end{array}$} & $n$ & 460 & 0 & 0 & 0 & 9 & 185 & 0 & 0 & 0 & 18 & 0 & 0 & 412 & 0 & 0 & 1084 \\
\hline & $\%$ & 42,44 & 0,00 & 0,00 & 0,00 & 0,83 & 17,07 & 0,00 & 0,00 & 0,00 & 1,66 & 0,00 & 0,00 & 38,01 & 0,00 & 0,00 & 100,00 \\
\hline \multirow[t]{2}{*}{ Szécsénke-BO-1 } & $n$ & 81 & 0 & 1 & 0 & 6 & 20 & 0 & 0 & 9 & 0 & 0 & 0 & 4 & 1 & 0 & 122 \\
\hline & $\%$ & 66,39 & 0,00 & 0,82 & 0,00 & 4,92 & 16,39 & 0,00 & 0,00 & 7,38 & 0,00 & 0,00 & 0,00 & 3,28 & 0,82 & 0,00 & 100,00 \\
\hline \multirow[t]{2}{*}{ Szécsénke-BO-2E } & $n$ & 84 & 0 & 3 & 0 & 4 & 52 & 0 & 0 & 8 & 7 & 1 & 0 & 0 & 1 & 1 & 161 \\
\hline & $\%$ & 52,17 & 0,00 & 1,86 & 0,00 & 2,48 & 32,30 & 0,00 & 0,00 & 4,97 & 4,35 & 0,62 & 0,00 & 0,00 & 0,62 & 0,62 & 100,00 \\
\hline \multirow[t]{2}{*}{ Szécsénke-BO-2W } & $n$ & 148 & 0 & 5 & 0 & 9 & 34 & 0 & 0 & 43 & 7 & 0 & 1 & 15 & 0 & 0 & 262 \\
\hline & $\%$ & 56,49 & 0,00 & 1,91 & 0,00 & 3,44 & 12,98 & 0,00 & 0,00 & 16,41 & 2,67 & 0,00 & 0,38 & 5,73 & 0,00 & 0,00 & 100,00 \\
\hline \multirow[t]{2}{*}{ Szécsénke-BO-3 } & $n$ & 434 & 3 & 8 & 1 & 25 & 78 & 0 & 0 & 30 & 6 & 0 & 0 & 48 & 0 & 0 & 633 \\
\hline & $\%$ & 68,56 & 0,47 & 1,26 & 0,16 & 3,95 & 12,32 & 0,00 & 0,00 & 4,74 & 0,95 & 0,00 & 0,00 & 7,58 & 0,00 & 0,00 & 100,00 \\
\hline \multirow[t]{2}{*}{$\begin{array}{l}\text { Kétbodony- } \\
\text { Halyagos-hegy }\end{array}$} & $n$ & 242 & 0 & 0 & 0 & 1 & 26 & 1 & 0 & 18 & 16 & 1 & 2 & 142 & 3 & 7 & 459 \\
\hline & $\%$ & 52,72 & 0,00 & 0,00 & 0,00 & 0,22 & 5,66 & 0,22 & 0,00 & 3,92 & 3,49 & 0,22 & 0,44 & 30,94 & 0,65 & 1,53 & 100,00 \\
\hline \multirow[t]{2}{*}{ Legénd-Rovnya } & $n$ & 756 & 2 & 0 & 0 & 19 & 166 & 0 & 0 & 0 & 13 & 5 & 0 & 5 & 6 & 0 & 972 \\
\hline & $\%$ & 77,78 & 0,21 & 0,00 & 0,00 & 1,95 & 17,08 & 0,00 & 0,00 & 0,00 & 1,34 & 0,51 & 0,00 & 0,51 & 0,62 & 0,00 & 100,00 \\
\hline
\end{tabular}

Table 1. Szécsénke site complex, distribution of artefacts according to raw materials. //

1. táblázat. Szécsénke lelőhelykomplexum, leletek megoszlása nyersanyag szerint.

A. Markó made a very interesting statement about the distribution of the felsitic porphyry is his paper dealing with the small Szeletian-like assemblage with leaf-points of Debercsény-Mogyorós (Markó 2009b). The spread of this raw material reaches its maximum in the Szeletian period compared with the Micoquian-Bábonyian period, and at the same time the intensity of the utilization eases down.

This maximum spread is about $340 \mathrm{~km}$ in the cases of Ondratice I. and Ořechow II. sites in Moravia. There is a leaf-point both in Ořechow II. (Čermáková 1993: 9, Obr. 1:5; Valoch 2000:292) and in Ondratice I. (Valoch 1987: 266; Valoch 2000: 292) made of felsitic porphyry. The above statement should have a partial validity. The decrease or even the lack of felsitic porphyry could be observed at the Legénd-Rovnya (LGR) site (Péntek-Zandler 2013b) as well as at the Buják-Szente site (Péntek-Zandler 2014). That should be the case at the other above discussed sites at Szécsénke too, exclusive of the KFH and HH sites, under the presumption these two latter sites are belonging to the earlier phase of the Szeletian. A plausible explanation for the decrease of the amount of the felsitic porphyry should be the assumption, that in the younger, developed phase of the Szeletian either it comes through or sustains a kind of "depreciation" or the outcrops were eventually not available. Unfortunately we do not even know whether the decrease was a gradual process, or a sudden, abrupt event. 


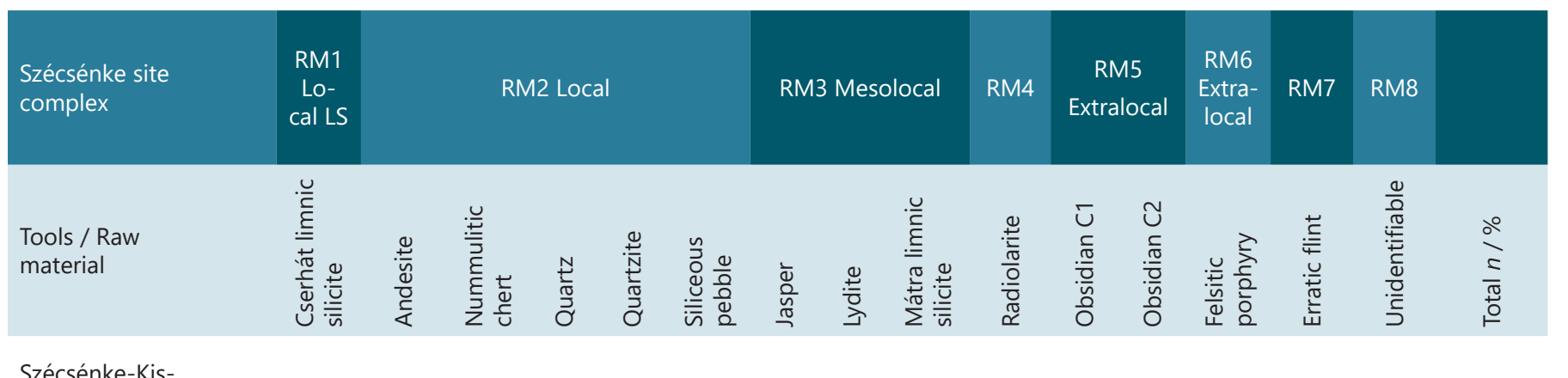

Szécsénke-Kis-

Ferenc-hegy

$$
\begin{array}{lllllllllllllllll}
n & 21 & 0 & 0 & 0 & 3 & 37 & 0 & 0 & 0 & 5 & 0 & 0 & 53 & 0 & 0 & 119
\end{array}
$$

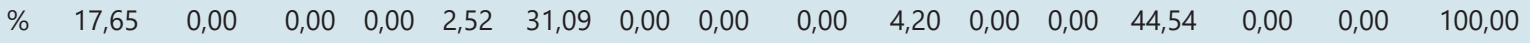

Szécsénke-BO-1 $n \quad \begin{array}{lllllllllllllllllllllll} & 0 & 0 & 0 & 0 & 0 & 3 & 0 & 0 & 3 & 0 & 0 & 0 & 2 & 0 & 0 & 8\end{array}$

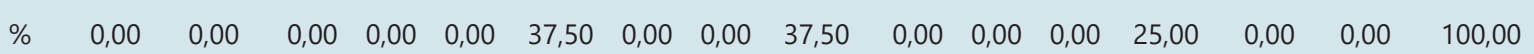







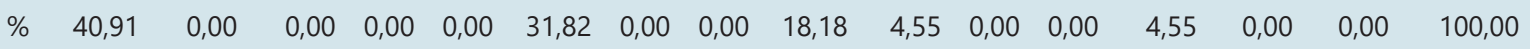

$\begin{array}{llllllllllllllllllllll}\text { Szécsénke-BO-3 } & n & 8 & 0 & 0 & 1 & 0 & 14 & 0 & 0 & 2 & 3 & 0 & 0 & 3 & 0 & 0 & 31\end{array}$

\begin{tabular}{|c|c|c|c|c|c|c|c|c|c|c|c|c|c|}
\hline 2581 & 0,00 & 0,00 & 3,2 & 0,00 & 45,16 & 0,00 & 0,00 & 6,45 & 9,68 & 0,00 & 0,00 & 9,68 & 100,00 \\
\hline
\end{tabular}

Kétbodony-

Halyagos-hegy

$\begin{array}{llllllllllllllllll}n & 2 & 0 & 0 & 0 & 0 & 0 & 0 & 0 & 3 & 1 & 0 & 0 & 4 & 0 & 3\end{array}$

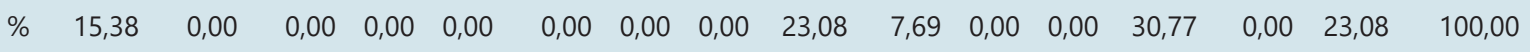

$\begin{array}{rrrrrrrrrrrrrrrrrrrrrrrrrr}\text { Legénd-Rovnya } & n & 15 & 0 & 0 & 0 & 2 & 22 & 0 & 0 & 0 & 4 & 0 & 0 & 3 & 0 & 0 & 46 \\ & \% & 32,61 & 0,00 & 0,00 & 0,00 & 4,35 & 47,83 & 0,00 & 0,00 & 0,00 & 8,70 & 0,00 & 0,00 & 6,52 & 0,00 & 0,00 & 100,00\end{array}$

Table 2. Szécsénke site complex, distribution of tools according to raw materials. //

2. táblázat. Szécsénke lelőhelykomplexum, eszközök megoszlása nyersanyag szerint.

Beside the fact that the typological characteristics of the tools originating from the KFH site indicate the inherence to the Early Szeletian, it can be stated that these people had a substantial knowledge about the capacity of the region, among other thing about the local raw material resources. That is, for these people the stay at the KFH site was for sure not the very first time in the Cserhát Mountains. Taking into account the high amount of felsitic porphyry at several Late Middle Palaeolithic and Middle to Upper Palaeolithic transitional sites in the Cserhát Mountains it should be obviously assumed that a kind of "circulating settlement system" could have been existed here (Marks-Chabai 2001: 197 ff. after Mortensen 1972) based on the regular commute between the Bükk and the Cserhát Mountains.
Binford (Binford 1980: 5) made an essential distinction between a "foraging strategy" and a "logistic strategy". The main difference is how human groups move through landscape to acquire the necessary resources. With the "foraging strategy" people move to sources of nutrition ("circulating systems" sensu Mortensen 1972). With "logistical strategies" group members bring resources to the group's residential location ("radiating system" sensu Mortensen 1972).

In a "circulating system" a band of foragers moves through the landscape according to seasonal cycles and establishes campsites near to food resources. All incoming activities were done within such campsites, that is each settlement represents the range of activities carried out by the group 
during a short period of time. Each site could be regarded as self-sufficient. The "radiating settlement system" is also characterized by the existence of a central campsite (the focus of habitation) which is supplied by a set of action specific stations ("locations", Binford 1980: 9; "activity-specific sites”, Marks-Chabai 2001; Bernbeck 1997). These action specific stations could be correlated to the so-called "provisioning stations", stations for resource procurement, by G. Bataille (Bataille 2010: 69).

Unfortunately such long-term residential "base camps" could not be attested neither in the Bükk Mountains nor elsewhere at the southern foot of the Mátra Mountains, that is, the existence of a "radiating settlement system" could be excluded. In the early phase of the Szeletian, the regular wandering from the Bükk Mountains to the Cserhát Mountains must have been a "Getting from A to B" event. And it must have been a relatively rapid-flowing, insinuating action because in the intervening areas only very limited traces, that is only a little amount of felsitic porphyry, of this wandering could be found. In this early phase the regional raw material assortments from the Mátra Mountains are absolutely lacking. Some expansion or a further migration during the developing of the Szeletian industry in the direction of the Mátra Mountains should be thinkable. Weniger (Weniger 1991: 84) denotes movements within a local context area as micro moves, the relocation of a camp site into another local context area (,Nutzungsareal“) as macro moves. In a case of such "macro move", it could have been not impossible the unavailability or limited availability of the felsitic porphyry. And from that time the increased occurence of the regional raw materials originating from the Mátra Mountains at the sites in the Cserhát Mountains which belong to this younger, developed phase of the Szeletian, is not surprising at all. This hypotethical model about felsitic porphyry exploitation of the Szeletian industry could not be applied to the Micoquian-Bábonyian industry. In the above described assemblage of Legénd-Káldy-tanya raw material from the Mátra Mountain region is abundant. It is unknown how and when they get in touch with the raw materials of the Mátra Mountains.

In connection with the recurrent occupation of the Late Middle Palaeolithic site Kabazi II in Crimea, G. Bataille remarked that, ,the high share of local raw material in connection with only few workpieces imported as single pieces emphasise that people already were present in the core region" (Bataille 2010: 70). The dominance of local raw material, such as limnic silicite, siliceous pebbles, nummulitic chert and quartzite and the joint occurence with imported tools could be observed at some sites at Szécsénke. At the BO-1 site for example there is a little assemblage containing 110 artefacts, the local raw materials dominate (limnic silicite with 70.91 $\%$, siliceous pebble with $14.55 \%$ ), there are very few or no debris of import raw materials. From the 8 tools there are 4 pieces made of local silex, 2-2 pieces are made of limnic silicite stemming from the Mátra Mountains and from felsitic porphyry.

In connection with the "G-Komplex" of Sesselfelsgrotte J. Richter (Richter 1997: 262; Richter 2001: 209 ff.) wrote that occupation cycles start with small assemblages of broad spectrum raw material procurement. He denotes these small assemblages as „Initialinventare”. This fact might mark the arrival of a given group in one region where never had been before, coming from a remote one, a so-called macro move sensu Weniger (Weniger 1991). Dispersed and heterogenous raw materials will be used. The occupation cycles end with mostly larger assemblages of more specialized raw material procurement. Occupations marked by the utilization of few different and primarily local raw material sources will be called as „Konsekutivinventare”, since groups already dwell for a longer period of time in a given region. Initialinventare might originate from the beginning reconnaissance and exploitation of a region whereas Konsekutivinventare document a deeper knowledge of resources and might arise from a time when people had already been present in the region for weeks or months.

Taking into consideration the above mentioned aspects of the discussed site complex at Szécsénke, there is an apparently contradictionary situation. On the basis of the techno-typological features, the KFH site seem to belonging the earlier phase, the other sites, apart from the $\mathrm{HH}$ site, with its most probably inhomogeneous archaeological material, are belonging to a younger, developed phase of the Szeletian industry. Hence, a genetic or diachronic developmental sequence could be established. But taking into account the raw material composition, there is a somewhat reversed hierarchy among the sites. The collection from the KFH site seems to represent a consecutive assemblage with a wellbalanced steady raw material composition which document a deeper knowledge of resources. This knowledge might arise from the time when people had already been in the region. At the same time, all the other collections with both regional raw materials from the Mátra Mountains as with long distance raw materials represent initial assemblages.

This and other kinds of seemingly contradictory problems would be cleared only due to excavations or at least test sondages.

Acknowledgements: I would like to express my gratitude to Zsolt Mester and Attila Király for their technical advices.

\section{References}

Baales, M. 1999. Economy and Seasonality in the Ahrensburgian. In: Kozłowski, S. K., Gruba, J., Zaliznyak, H. H. (Hrsg.): Tanged points cultures in Europe. Kolloquium Lublin 1993. Lubelskie materialy archeologiczne 13. Lublin, 64-75.

Baang-Andersen, S. 2008. Prehistoric reindeer hunting in the southern Norwegian highlands. In: Grimaldi, S., Perrin, T. (eds.) Mountain environments in prehistoric Europe: settlement and mobility strategies from the Palaeolithic to the Early Bronze Age. Proceedings of the XVth World Congress (Lisbon, 4-9 September 2006) Oxford: Archaeopress, 63-70.

Bataille, G. 2010. Recurrent occupations of the Late Middle Palaeolithic Station Kabazi II, Unit II, Level 8 (Crimea, Ukraine) - Seasonal adaption, procurement and processing of resources. Quartär 57: 43-77. 
Bataille, G. 2012. Stones and Bones. The Reconstruction of Occupational Palimpsests in the Late Middle Palaeolithic of Crimea (Ukraine). In: Cascalheira, J., Gonçalves, C. (eds.) Actas das IV Jornadas de Jovens em Investigação Arqueológica - JIA 2011(2) Promontoria Monográfica 16, Faro, 201-209.

Bernbeck, R. 1997. Theorien in der Archaologie. Tübingen - Basel 1997.

Biró, K. T. 1984. Őskőkori és őskori pattintott kőeszközeink nyersanyagának forrásai - Sources of Lithic Raw Materials for Chipped Implements in Hungary. Archaeológiai Értesítô 111: 42-52.

Biró, K. T., 1986. The raw material stock for chipped stone artefacts in the Northern Mid-Mountains Tertiary in Hungary. In: Biró, K. T. (ed.), Papers forthe 1st International Conference on Prehistoric Flint Mining and Lithic Raw Material Identification in the Carpathian Basin, Budapest-Sümeg 1986. Budapest: Magyar Nemzeti Múzeum, 183-195

Biró, K. T., Markó, A., Kasztovszky, Zs. 2005. 'Red' obsidian in the Hungarian Palaeolithic characterisation studies by PGAA. Praehistoria 6: 109-140.

Bluszcz, A., Kozłowski, J. K., Foltyn, E. 1994. New Sequence of EUP Leaf Point Industries in Southern Poland. Préhistoire Européenne 6: 197-222. https://doi.org/10.1016/0009-2614(94)00402-1

Bohmers, A., 1951. Die Höhlen von Mauern. Teil I. Kulturgeschichte der altsteinzeitlichen Besiedlung. Palaeohistoria 1: 1-107.

Bolus, M. 2004. Settlement analysis of sites of the Blattspitzen complex in Central Europe. In: Conard, N. (ed.) Settlement Dynamics of the Middle Paleolithic and Middle Stone Age. Vol. II. Tübingen: Kerns Verlag, 201-226.

Bosinski, G. 1967. Die mittelpaläolitische Funde im Westlichen Mitteleuropa. Köln-Graz: Böhlau-Verlag

Bosinski, G. 2000-2001. El Paleolítico Medio en Europa Central. Zephyrus 53-54: 79-142.

Burch, E. S. 1972. The Caribou/Wild Reindeer as a human resource. American Antiquity 37: 339-368. https://doi.org/10.2307/278435

Chabai, V. P., Uthmeier, T. 2006. Settlement Systems in the Crimean Middle Palaeolithic. In: Chabai, V. P., Richter, J., Uthmeier, T. (eds.) Kabazi II: The 70000 Years since the Last Interglacial. Simferopol - Cologne: Shlyak, 297-359.

Cheben, I., Cheben, M. 2010. Research on radiolarites of the White Carpathian Klippen Belt. Slovenská Archeológia 58(1): 13-52.

Chmielewski, W. 1961. La civilisation de Jerzmanowice. WrocławWarszawa-Kraków. Instytut Historii Kultury Materialnej Polskej Akademii Nauk

Conard, N. J., Fischer, B., 2000. Are there Recognizable Cultural Entities in the German Middle Palaeolithic? In: Ronen, A., Weinstein-Evron, M. (eds.), Towards Modern Humans: Yabrudian and Micoquian, 400-50 kyears ago. BAR International Series 850, Oxford, pp. 7-24.

Csongrádi-Balogh, É., Dobosi, V. 1995. Paleolithic settlement traces near Püspökhatvan. Folia Archaeologica 44: 37-59.

Čermáková (Nerudová), Z. 1993. Listovité hroty z lokality Ořechov II. Sborník prací Filozofické fakulty Brněnské Univerzity E 38: 7-14.

Derndarsky, M., 2001. Die Forschungen in und zu der Gudenushöhle. In: Daim, F., Kühtreiber, Th. (Hrsg.), Sinn \& Sein. Burg \& Mensch, Katalog der Niederösterreichischen Landesausstellung 2001. Katalog des Niederösterreichischen Landesmuseums, Neue Folge Nr. 434. St. Pölten: Niederösterreichisches Landesmuseum, 224-226.

Dobosi, V. T. 1978. A pattintott kőeszközök nyersanyagáról Über das Rohmaterial der retuschierten Steingeräte. Folia Archaeologica 29: 7-19.
Dobosi, V. T. 2011. Őskőkori lelőhelyek Romhány környékén. (Gyombola Gábor gyűjtése). Folia Archaeologica 55: 9-23.

Flas, D. 2006. La transition du Paléolithique moyen au supérieur dans la plaine septentrionale de l'Europe. Les problematiques du Lincombien-Ranisien-Jerzmanowicien. Thèse de doctorat soutenue le 25 août 2006 à l'université de Liège.

Flas, D. 2011. The Middle to Upper Paleolithic transition in Northern Europe: the Lincombian-Ranisian-Jerzmanowician and the issue of acculturation of the last Neanderthals. World Archaeology 43(4): 605-627. https://doi.org/10.1080/00438243.2011.624725

Gábori Csánk, V. 1993. Le Jankovichien. Une civilisation paléolithique en Hongrie. E.R.A.U.L. 53, Liège.

Gyalog, L., Budai, T. 2002. Javaslatok Magyarország földtani képzõdményeinek litosztratigráfiai tagolására. Proposal for new lithosratigraphic units of Hungary. A Magyar Állami Földtani Intézet Évi Jelentése 2002, 195-232.

Hámor, G. 1985. A Nógrád-cserháti kutatási terület földtani viszonyai. The geology of the Nógrád-Cserhát area. Geologica hungarica, Series geologica Tomus 22, Budapest

Heinen, M., Beck, D. 1997. Ausgrabungen auf dem SzeletienFundplatz Zeitlarn, Lkr. Regensburg. Beiträge zur Archäologie in der Oberpfalz 1: 71-88.

Hladíková, L. 2002. Szeletian chipped industry from Trboušany I. Časopis Moravského Musea 87: 57-80

Hopkinson, T. 2004. Leaf points, landscapes and environment change in the European Late Middle Palaeolithic. In: Conard, N. (ed.), Settlement Dynamics of the Middle Paleolithic and Middle Stone Age. Vol. II. Tübingen: Kerns Verlag, 227-258

Hülle, W. M. 1977. Die Ilsenhöhle unter Burg Ranis/Thüringen. Eine paläolithische Jägerstation. Stuttgart, Gustav Fischer Verlag

Jennings, T. A. 2011. Experimental production of bending and radial flake fractures and implications fro lithic technologies. Journal of Archaeological Science 30: 1-8.

Jöris, O. 2001. Der spätmittelpaläolithische Fundplatz Buhlen (Grabungen 1966-69) - Stratigraphie, Steinartefakte und Fauna des Oberen Fundplatzes. Bonn, Dr. Rudolf Habelt GmbH

Kaminská, L. 2001. Die Nutzung von Steinrohmaterialien im Paläolithikum der Slowakei. Quartär 51/52: 81-106.

Kaminská, L. 2013. Sources of raw materials and their use in the Palaeolithic of Slovakia. In: Mester, Zs. (ed.), Papers of the Visegrád fund project $n^{\circ}$ 21110211. Kraków-Budapest: Polish Academy of Arts and Sciences, Kraków and Institute of Archaeological Sciences of the Eötvös Loránd University, 99-110.

Korpás, L. (szerk.) 1998. Magyarázó a Börzsöny és a Visegrádi-hegység földtani térképéhez. Budapest: A Magyar Állami Földtani Intézet Térképmagyarázói

Kozłowski, J. K., Mester, Zs. 2003-2004. Un nouveau site du Paléolithique supérieur dans la région d'Eger (Nord-est de la Hongrie). Praehistoria 4-5: 109-140.

Kozłowski, J. K. 2013. Raw materials procurement in the Late Gravettian of the Carpathian Basin. In: Mester, Zs. (szerk.) The lithic raw material sources and interregional human contacts in the Northern Carpathian regions. Krakkó: Polska Akademia Umiejętności Archiwum Nauki PAN i PAU, 63-86.

Kuhn, S. L. 1995. Mousterian Lithic Technology. An Ecological Perspective. Princeton, N. J.: Princeton University Press. https:// doi.org/10.1515/9781400864034

Láng, S. 1967. A Cserhát természeti földrajza. Budapest: Akadémiai Kiadó

Mania, D. 1990. Auf den Spuren des Urmenschen. Die Funde von Bilzingsleben. Berlin-Stuttgart: Deutscher Verlag der 
Wissenschaften, Theiss Verlag

Markó, A. 2004. Újabb kőeszköz a galgagyörki Csonkás-hegyről. Ősrégészeti Levelek. Prehistoric Newsletter 6: 10-12.

Markó, A. 2005. Limnokvarcit a Cserhát hegységben. Archeometriai Múhely 2005/4: 52-55.

Markó, A. 2007. Preliminary report on the excavations of the middle palaeolithic site Vanyarc - Szlovácka-dolina. Communicationes Archaeologicae Hungaricae: 5-18.

Markó, A. 2009a. Raw material circulation during the Middle Palaeolithic period in northern Hungary, In: Ganczarski, J. (red.), Surowce naturalne $w$ Karpatach oraz ich wykorzystanie $w$ pradziejach i wczesnym średniowieczu. Krosno: 107-119.

Markó, A. 2009b. Levéleszközös leletegyüttes Debercsényből. Leafshaped industry from Debercsény. Archeológiai Értesítő 134: 155163. https://doi.org/10.1556/ArchErt.134.2009.9

Markó, A. 2012. Középsố-paleolitikus leletegyüttesek Vanyarc környékén. Doctoral thesis. Manuscript, Budapest: ELTE-BTK

Markó, A., Péntek, A., Béres, S. 2002. Chipped stone assemblages from the environs of Galgagyörk (Northern Hungary). Praehistoria 3: 245-257.

Markó, A., Bíró, K., Kasztovszky, Zs. 2003. Szeletian felsitic porphyry: non-destructive analysis of a classical palaeolithic raw material. Acta Archaeologica Scientiarum Hungaricae 54: 297-314. https:// doi.org/10.1556/AArch.54.2003.3-4.1

Markó, A., Péntek, A. 2003-2004. Raw material procurement strategy on the palaeolithic site of Legénd Káldy-tanya (Cserhát Mountains, Northern Hungary). Praehistoria 4-5: 165-177.

Markó, A., Kázmér, M. 2004. The use of nummulitic chert in the Middle Palaeolithic in Hungary. In: Fülöp, É., Cseh, J. (szerk.), Die aktuellen Fragen des Mittelpaläolithikums in Mitteleuropa Topical issues of research of Middle Palaeolithic period in Central Europe Tata: Komárom-Esztergom County Museum Directorate, 53-64.

Marks, A. E., Chabai, V. P. 2001. Constructing Middle Palaeolithic settlement systems in Crimea: potentials and limitations. In: Conard, N. J. (ed), Settlement dynamics of the Middle Paleolithic and Middle Stone Age. Tübingen, Kerns Verlag, 179-204.

Mester, Zs. 2008-2009. Les outils foliacés de la grotte Jankovich : la renaissance d'un problème ancien. Praehistoria 9-10: 81-98.

Mester, Zs. 2010. Technological analysis of Szeletian bifacial points from Szeleta Cave (Hungary). Human Evolution 24(1-2): 107-124.

Mester, Zs. 2011. A magyarországi középső és felső paleolitikum bifaciális levéleszközeinek technológiája. In: Bíró K., Markó A. (szerk.), Emlékkönyv Violának. Tanulmányok T. Dobosi Viola tiszteletére. Papers in honour of Viola T. Dobosi. Budapest: Magyar Nemzeti Múzeum, 15-42.

Nerudová, Z. 1996. Szeletienská kolekce z Jezeřan I a její vztah $\mathrm{k}$ micoquienu $=\mathrm{La}$ collection széletienne de Jezeřany $\mathrm{I}$ et sa relation avec le Micoquien. Acta Musei Moraviae 81: 13-36.

Nerudová, Z. 2008-2009. The Technology of the Szeletian Lithic Industry in the Context of Moravian EUP Cultures. Praehistoria 9-10: 47-60.

Nigst, P.R., 2006. The first modern humans in the Middle Danube Area? New evidence from Willendorf II (eastern Austria). In: Conard, N. J. (ed.), When Neanderthals and Modern Humans Met. Tübingen: Kerns Verlag, 269-304.

Oliva, M. 1979. Die Herkunft des Szeletien im Lichte neuer Funde von Jezeřany. Acta Musei Moraviae 64: 45-78.

Oliva, M. 1992. The Szeletian occupation of Moravia, Slovakia and Bohemia. Acta Musei Moraviae 77: 35-50.

Oliva, M. 1995. Le Séletien de Tchécoslovaqiue: industrie lithique et répartion géographique. Paléo Supplement 1995, pp. 83-90. https://doi.org/10.3406/pal.1995.1383

Péntek, A. 2015a. Open air site with leaf-points at Legénd-Rovnya (Cserhát Mountains, North Hungary). Unpublished paper. https://www.academia.edu/19305468/A._P\%C3\%A9ntek_ Open_air_site_with_leaf-points_at_Leg\%C3\%A9nd-Rovnya_ Cserh\%C3\%A1t_Mountains_North_Hungary

Péntek, A. 2015b. Quartz and quartzite as raw materials in the Hungarian Palaeolithic. Unpublished paper. https://www. academia.edu/19726218/A._P\%C3\%A9ntek_Quartz_and_ quartzite_as_raw_materials_in_the_Hungarian_Palaeolithic

Péntek, A., Zandler, K. 2013a. Nyíltszíni Szeletien telep SzécsénkeKis-Ferenc-hegyen. Litikum 1: 36-49.

Péntek, A., Zandler, K. 2013b. Nyíltszíni levéleszközös telep LegéndRovnyán. Open-air Site with Leaf-points at Legénd-Rovnya. Neograd. A Dornyay Béla Múzeum Évkönyve 37: 23-45.

Péntek, A., Zandler, K. 2014. Buják-Szente, egy nyíltszíni paleolit telep. Litikum 2: 3-16.

Prošek, Fr. 1953. Le Szeletien en Slovaquie. Slovenská Archeológia 1: 178-194.

Přichystal, A. 2010. Classification of lithic raw materials used for prehistoric chipped artefacts in general and siliceous sediments (silicites) in particular: the Czech proposal - Javaslat a pattintott kőeszközök készítésére használt kőeszközök osztályozására, általános tekintetben, különös tekintettel a kovakőzetekre és a kovás üledékekre. Archeometriai Múhely 2013/3: 177-181

Richter, J. 1997. Sesselfelsgrotte III. Der G-Schichten-Komplex der Sesselfelsgrotte - Zum Verständnis des Micoquien. QuartärBibliothek Band 7. Saarbrücken: Saarbrücker Druckerei und Verlag

Richter, J. 2001. For lack of a wise old man? Late Neanderthal landuse patterns in the Altmühl River Valley; Bavaria. In: Conard, N. J. (ed.) Settlement Dynamics of the Middle Paleolithic and Middle Stone Age, Vol. 1. Tübingen: Kerns Verlag, 205-219.

Ringer, Á. 1983. Bábonyien - Eine mittelpaläolitische Blattwerkzeugindustrie in Nordostungarn. Dissertationes Archaeologicae Ser. II. No. 11, Budapest

Ringer, Á., Mester, Zs. 2000. Résultats de la révision de la grotte Szeleta entreprises en 1999 et 2000. Anthropologie (Brno) 38: 261-270.

Rosania, C. N., Boulanger, M. T., Bíró K., Ryzhov, S., Trnka, G., Glascock, M. D. 2008. Revisiting Carpathian obsidian. Antiquity $82(318)$

Schönweiss, W., Werner, H.-J. 1986. Ein Fundplatz des Szeletien in Zeitlarn bei Regensburg. Archäologisches Korrespondenzblatt 16(1): 7-12.

Simán, K. 1985. Paleolit leletek Sajószentpéteren. A Herman Ottó Múzeum Évkönyve 22-23: 9-20.

Simán, K. 1993. Őskőkori leletek Nógrád megyében. Fünde aus der Vorzeit im Komitat Nógrád. A Nógrád Megyei Múzeumok Évkönyve 18: 247-252.

Simán, K. 1999. Bifaciális eszközök Korlát-Ravaszlyuk-tető lelőhelyen (Bifacial implements on Korlát-Ravaszlyuk-tető site). A Herman Ottó Múzeum Évkönyve 37: 29-44.

Škrdla, P., Nejman, L., Rychtař́íková, T., Nikolajev, Lisá, L. 2014. New observations concerning the Szeletian in Moravia. Quartär 61: 87-101.

Svoboda, J., Přichystal, A. 1987. Szeletská industrie z Vincencova (Otaslavice, okr. Prostějov). Szeletian industry from Vincencov (Otaslavice near Prostéjov). Acta Musei Moraviae 52: 5-19.

Trnka, G. 1990. Ein neuer paläolithischer Blattspitzenfund aus 
Schletz in Niederösterreich. Archäologie Österreichs 1(1-2): $20-24$.

Valoch, K. 1955. Die Erforschung der paläolitischen Fundstätte in Rozdrojovice bei Brünn. Acta Musei Moraviae 40: 5-32.

Valoch, K. 1960. Die Blattspitzenindustrie von Ořechov bei Brno (Brünn). (Zugleich ein Beitrag zur Problematik des Szeletien). Anthropozoikum 10: 35-47.

Valoch, K. 1966. Die altertümlichen Blattspitzenindustrie von Jezeřany (Südmähren). Acta Musei Moraviae 51: 5-60.

Valoch, K. 1967. Die altsteinzeitlichen Stationen im Raum von Ondratice in Mähren. Acta Musei Moraviae 52: 5-45.

Valoch, K. 1973. Neslovice, eine bedeutende Oberflächenfundstelle des Szeletien in Mähren. Acta Musei Moraviae 58: 5-76.

Valoch, K. 1987. The raw materials used in the Moravian Middle and Upper Palaeolithic. In: Biró, K. T. (ed.), Papers forthe 1st International Conference on Prehistoric Flint Mining and Lithic Raw Material Identification in the Carpathian Basin, Budapest-Sümeg 1986. Budapest: Magyar Nemzeti Múzeum, 263-268.

Valoch, K. 1993. Vedrovice V, eine Siedlung des Szeletien in Südmähren. Quartär 43-44: 7-93.

Valoch, K. 2000. Das Szeletien Mährens - seine Wurzeln und Beziehungen. In: Mester, Zs., Ringer, Á. (dir.), A la recherche de l'Homme Préhistorique, Volume commémoratif de Miklós Gábori et de Veronika Gábori-Csánk. ERAUL 95, Liège, 287-294.

van der Drift, J. W. P. 2009. Bipolar technique in the Old Palaeolithic. Aktieve Praktijk Archeologie Nederland, APAN/extern:1-15. https:// doi.org/10.5117/NEDTAA2010.1.DISC421

Veil, S., Breest, K., Höfle, H.-C., Meyer, H.-H., Plisson, H., Urban-Küttel, B., Wagner, G.A., Zöller, L. 1994. Ein mittelpaläolithischer Fundplatz aus der Weichsel-Kaltzeit in der norddeutschen Tiefebene bei Lichtenberg. Landkreis LüchowDannenberg. Zwischenbericht über die archäologischen und geowissenschaftlichen Untersuchungen 1987-1992. Germania 72: $1-65$.

Verpoorte, A. 2006. Neanderthal energetics and spatial behaviour. Before Farming 2006/3: 1-6. https://doi.org/10.3828/ bfarm.2006.3.2

Vértes, L. 1951. Мезолитические находки на вершине горы Кёпорош при г. Эгер (Венгрия). Acta Archaeologica Academiae Scientiarum Hungaricae 1: 153-190.

Weniger, G.-C.1991.Überlegungen zur Mobilitätjägerischer Gruppen im Jungpaläolithikum. Urgeschichte als Kulturanthropologie. Beiträge zum 70. Geburtstag von Karl J. Narr, Teil II. Saeculum 24(1): 82-103. https://doi.org/10.7788/saeculum.1991.42.1.82

White, R. 1989. Husbandry and herd control in the upper Paleolithic; A critical review of the Evidence. Current Anthropology 30: 609632. https://doi.org/10.1086/203789

Zandler, K. 2006. Paleolit lelöhelyek Eger környékén. Egyetemi szakdolgozat. Kézirat. ELTE-BTK Budapest.

Zandler, K. 2008. Nyíltszíni paleolit lelőhely Erdőtarcsa-Daróci hegyen. Open-air Palaeolithic site at Erdőtarcsa-Daróci-hegy. Paläolitische Freilandstation in Erdőtarcsa-Daróci-Berg. A Nógrád Megyei Múzeumok Évkönyve 32: 46-66.

Zandler, K. 2010. Paleolit telep Hont-Csitáron. A palaeolithic site at Hont-Csitár. In: Guba Sz., Tankó, K. (eds.), „Régrôl kell kezdenünk..." Studia Archaeologica in honorem Pauli Patay. Régészeti tanulmányok Nógrád megyéból Patay Pál tiszteletére. Szécsény: Nógrád Megyei Múzeumok Igazgatósága, 23-49.

Zandler, K. 2012a. Késő középső és felső paleolit szórvány leletek Hont-Babatról. A Nógrád Megyei Múzeumok Évkönyve 36: 105-120.
Zandler, K. 2012b. A paleolitikum kőiparai Eger környékén. Gesta 11: 147-203.

Zandler, K., Béres, S. 2011. Három nyíltszíni paleolit lelőhely reviziója: Bükkmogyorósd, Csokvaomány, Nekézseny. Revision of three open-air palaeolithic sites in the Bükk Mountains, NEHungary. In: Biró, T. K., Markó, A. (eds.), Emlékkönyv Violának. Tanulmányok T. Dobosi Viola tiszteletére. Papers in honour of Viola T. Dobosi. Budapest: Magyar Nemzeti Múzeum, 55-76

Zandler, K., Béres, S. 2014. Revision of three open-air palaeolithic sites in the Bükk Mountains, NE-Hungary. In: Biró, K. T., Markó, A., Bajnok, K. P. (eds.), Aeolian scripts. New ideas on the lithic world. Studies in honour of Viola T. Dobosi. Inventaria Praehistorica Hungariae XIII. Budapest: Magyar Nemzeti Múzeum, 63-76.

Zotz, L. F. 1955. Das Paläolithikum in den Weinberghöhlen bei Mauern. Ludwig Röhrscheid Verlag Bonn. Quartär-Bibliothek, Bd. 2. Bonn: Ludwig Röhrscheid Verlag

Zotz, L. F. 1959. Kösten, ein Werkplatz des Praesolutréen in Oberfranken. Quartär-Bibliothek, Bd. 3. Bonn: Ludwig Röhrscheid Verlag

\section{SKAM 2014 Article}

This study was presented at the 11th SKAM Lithic Workshop: the multifaceted biface - Bifacial technology in Prehistory. 20th-22nd of October, 2014, Miskolc, Hungary. The conference papers are published in the Litikum Journal volumes as special contributions. Informations about the conference are available on the SKAM 2014 website: http:// skam.pannontenger.hu 